\title{
Climate in continental interior Asia during the longest interglacial of the past 500000 years: the new MIS 11 records from Lake Baikal, SE Siberia
}

\author{
A. A. Prokopenko ${ }^{1}$, E. V. Bezrukova ${ }^{2}$, G. K. Khursevich ${ }^{3}$, E. P. Solotchina ${ }^{4}$, M. I. Kuzmin ${ }^{2}$, and P. E. Tarasov ${ }^{5}$ \\ ${ }^{1}$ Department of Earth and Ocean Sciences, University of South Carolina, Columbia, SC, USA \\ ${ }^{2}$ Institute of Geochemistry, Siberian Branch of Russian Academy of Sciences, Irkutsk, Russia \\ ${ }^{3}$ Department of Botany, M. Tank State Pedagogical University, Minsk, Belarus \\ ${ }^{4}$ Institute of Geology and Mineralogy, Siberian Branch of Russian Academy of Sciences, Novosibirsk, Russia \\ ${ }^{5}$ Freie Universität Berlin, Geological Sciences, Palaeontology Section, Berlin, Germany
}

Received: 2 June 2009 - Published in Clim. Past Discuss.: 17 July 2009

Revised: 3 December 2009 - Accepted: 14 December 2009 - Published: 20 January 2010

\begin{abstract}
A synthesis of paleoclimate responses from Lake Baikal during the MIS 11 interglacial is presented based on proxy records from two drill sites $245 \mathrm{~km}$ apart. BDP-99 is located in vicinity of the delta of the major Baikal tributary, whereas the BDP-96 site represents hemipelagic setting distant from riverine influence. The comparison of thicknesses of interglacial intervals in these contrasting depositional settings confirms the extended ca. 33-kyr duration of the MIS 11 interglacial. The new BDP-99 diatom biostratigraphic record matches that of the BDP-96-2 holostratotype and thus allows establishing establishes robust correlation between the records on the same orbitally-tuned timescale.

The first detailed MIS 11 palynological record from the BDP-99 drill core indicates the dominance of boreal conifer (taiga) forest vegetation in the Baikal region throughout the MIS 11 interglacial, since at least $424 \mathrm{ka}$ till ca. $396 \mathrm{ka}$. The interval ca. 420-405 ka stands out as a "conifer optimum" with abundant Abies sibirica, indicative of climate significantly warmer and less continental than today. The closest Baikal analog to this type of vegetation in the history of the current Holocene interglacial is at ca. 9-7 ka. The warm conifer phase lasted for ca. $15 \mathrm{kyr}$ during MIS 11 interrupted by two millennial-scale cooling episodes at ca. 411-410 and $405-404 \mathrm{ka}$. Reconstructed annual precipitation of 450$550 \mathrm{~mm} / \mathrm{yr}$ during the MIS 11 interglacial is by ca. $100 \mathrm{~mm}$ higher than during the Holocene; regional climate was less continental with warmer mean temperatures both in summer and in winter.
\end{abstract}

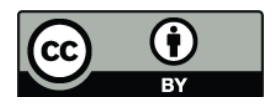

Correspondence to: A. A. Prokopenko (sasha@geol.sc.edu)
At both drill sites, the two-peak structure of the MIS 11 diatom abundance profiles reflects the orbital signature of precession in the interglacial paleoclimate record of continental Eurasia. MIS 11 interglacial was characterized by the sustained high level of primary production and accumulation of autochthonous organic matter at both study sites. The responses of paleoclimate-sensitive indices in the mineralogy of the MIS 11 sediments in BDP-96-2 are consistent with those during the Holocene. Illitization of secondary clay minerals in the Baikal watershed was an important process, but it appears to have been subdued during the first half of the MIS 11, apparently due to elevated humidity and muted seasonality of regional climate.

\section{Past interglacials as potential analogs to modern and future climates}

The ability to predict future changes in global climate is essential for policymaking today and for human well-being in future, it relies on the ability to successfully model climatic conditions known to have existed in the past. Instrumental and even historic records of past climates do not extend beyond the very late portion of the current Holocene interglacial, which lasted since ca. $11.7 \mathrm{ka}$. To gain a better understanding of the climate of earlier periods, different geologic archives are studied for paleoclimate proxy records.

The dominant paradigm in paleoclimate research recognizes cyclic changes of global climate as a combined effect of the Earth's orbital configuration (Milankovitch forcing) and internal feedback mechanisms. Thus, the current interglacial is not unique in the sense that more or less similar

Published by Copernicus Publications on behalf of the European Geosciences Union. 


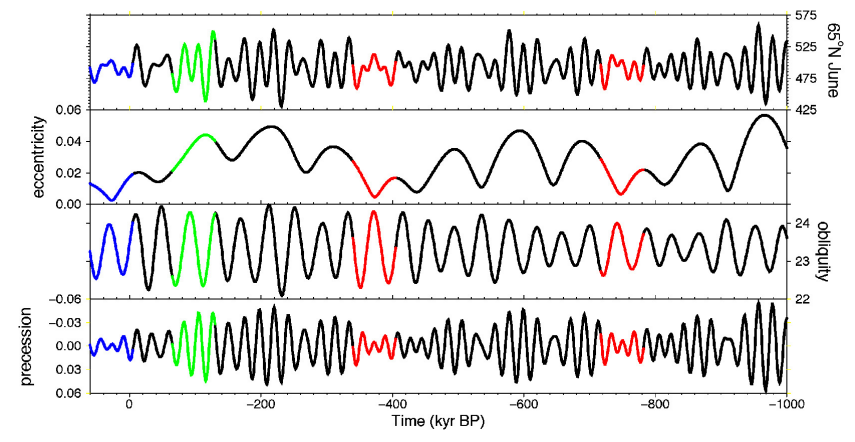

Fig. 1. Cyclic changes of orbital parameters and the Northern Hemisphere high latitude insolation during the past 1 Ma (Berger et al., 1993). Red portions of respective curves are the closest analogs to the orbital configuration at present and in nearest future (blue); green portion corresponds to the last interglacial, an unlikely orbital analog of the present interglacial (Loutre and Berger, 2003). The figure courtesy of M-F. Loutre.

interglacials have repeatedly occurred in past. Studies of the past analogs of the current Holocene interglacial are therefore important for capturing the natural range of variability of interglacial climates and for testing the current ideas on stability and operational modes of the global climate system. This knowledge is essential for developing new generations of climate models. The closer the apparent past analog is to the Holocene, the more relevant the study of this past interglacial becomes to the discussion of the future climate scenarios.

Even though interglacials have occurred every $\sim 80$ $100 \mathrm{kyr}$ (3-4 orbital precession cycles apart) during the past $1 \mathrm{Ma}$, finding a potential analog to the Holocene is not easy: it is important to find periods with similar orbital configurations, which provide analogous principal boundary conditions. Such orbital configuration analogs to the Holocene (a nearly circular orbit and subdued amplitudes of orbital parameter variations, Fig. 1, blue) are few; for instance, only two intervals satisfy the "similar orbital configuration" criterion during the past $1 \mathrm{Ma}$ (MIS 11 and MIS 19 intervals, Fig. 1, red). The last interglacial (Fig. 1, green) is a less likely analog because of high amplitudes of orbital parameter variations (Loutre and Berger, 2003; Loutre, personal communication, 2003). Recognition of MIS 11 as a potential analog to the current and possibly future interglacial in lieu of MIS 5e prompted a number of special sessions and volumes dedicated to MIS 11 in the past decade (e.g. Howard, 1997; Droxler et al., 2003). MIS 11 paleoclimate records consistently suggest that the atmospheric $\mathrm{CO}_{2}$ level (EPICA Community Members, 2004; Raynaud et al., 2005), ice volume and sea surface temperature in North Atlantic (McManus et al., 2003) were indeed quite similar to those during the Holocene, thereby reinforcing the potential analogy.

\section{Past interglacials in continental records and the continuous Pleistocene record from Lake Baikal}

To gain a perspective on climate of past interglacials it is important to establish a geographic network of sites and compare multiple regional proxy records. In continuous marine oxygen stable isotope records from deepwater depositional setting, the MIS 11 interval is readily recognized from the characteristic high amplitude of the MIS 12-11 transition and from the apparent duration of the $\delta^{18} \mathrm{O}$ minimum, which reflects the prolonged interval of low global ice volume. Marine MIS 11 intervals may be confidently correlated over long distances to study the spatial patterns of the past, such as changes in major ocean currents, rates of deepwater formation and past positions of the polar front.

In the mid-high-latitude continental records interglacials are recognized as intervals of expansion of thermophilic arboreal flora. However, because sediment deposition on continents changed greatly in response to environmental changes, it is difficult to find sites where long continuous Pleistocene sedimentary records are preserved. None exist in mid-high latitudes in Europe, where glaciations repeatedly obliterated prior sedimentary sequences. In non-glaciated areas long sequences of eolian deposits recorded past glacial-interglacial cycles as alternating loess/soil intervals, yet these sediments preserve few biological proxies. Some of the best continental archives of past interglacials are lake sediments. In addition to preserving pollen records of past interglacials, they contain lacustrine proxies for changes in primary productivity in response to changes in organic matter and nutrient input from respective catchments. In formerly glaciated areas, these lake sediments are found as lenses between the deposits of a prior and the subsequent ice ages. Based on pollen successions and stratigraphic considerations, such intervals are spliced to represent regional histories of past glacial-interglacial cycles and correlated across different regions. Because of the discontinuous nature of the sedimentary records, however, it has been difficult to unequivocally establish correlations of terrestrial interglacials with odd (interglacial) marine oxygen isotope stages. This is true for the MIS 11 interglacial as well (e.g. Nitychoruk et al., 2006).

Long continuous continental palynological records of several interglacials in a single record at a single site were obtained in southern Europe. Lacustrine sediment sequences in Massif Central, France and in Greece include the equivalents of the MIS 11 interglacial (e.g. Tzedakis et al., 1997; Reille et al., 2000). The Lake Baikal sediments contain the only known continuous lacustrine record of several glacialinterglacial cycles in the Eurasian mid-latitudes to the east of these sites. 


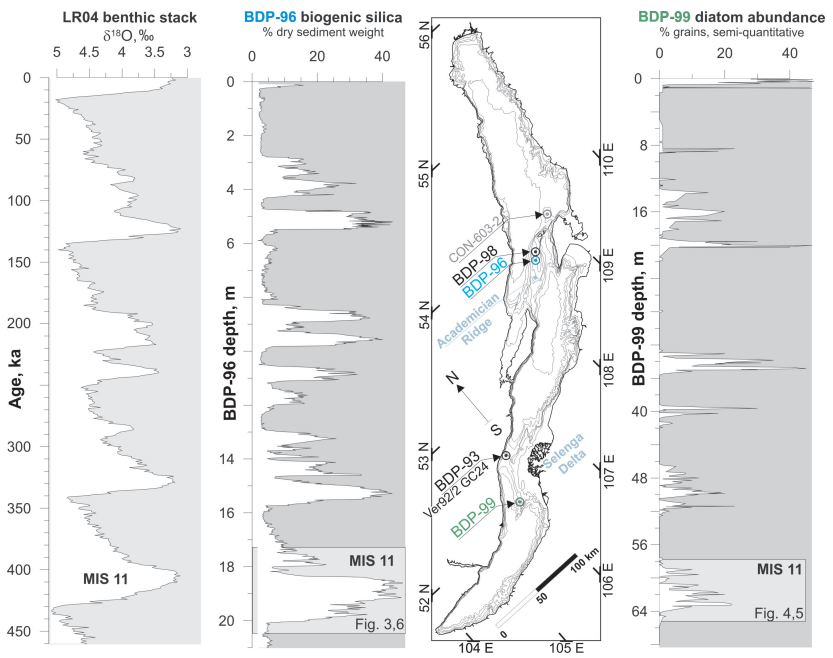

Fig. 2. Bathymetric map of Lake Baikal showing sediment core locations and the records of the last four climatic cycles reflected by biogenic silica and diatom abundance at the BDP-96 (Prokopenko et al., 2006) and BDP-99 (BDP Members, 2005) drill sites. The records are plotted to depth (note the differences in scale) and compared with the LR04 benthic marine oxygen isotope stack (Lisiecki and Raymo, 2005).

\section{MIS 11 in the Lake Baikal record and the objective of the current study}

The sedimentary record of Lake Baikal is one of the few continental archives containing paleoclimate proxy records of past Pleistocene interglacials in a continuous sedimentary sequence, which accumulated in a relatively stable depositional setting. By now, the MIS 11 interglacial interval in the Baikal record is unequivocally identified and recovered in four drill cores (BDP-96-1, BDP-96-2, BDP-98 and BDP-99) (Fig. 2), of which BDP-96-2 is the most complete and BDP-99 has the highest resolution. Previous studies touching on or specifically dedicated to the MIS 11 proxy responses dealt with biogenic silica content (BioSi) and/or diatoms (Prokopenko et al., 2001a; Karabanov et al., 2003; Mackay et al., 2008). Here we present new parallel high-resolution records of Lake Baikal productivity proxies and pollen for the MIS 11 interval in the most recent BDP-99 drill core. The key advantages of BDP-99 are (1) highest average MIS 11 sedimentation rate among sampled Baikal sites and (2) the location in the area affected by the suspended load of Selenga River, the main tributary of Lake Baikal (Fig. 2). The latter ensures rich pollen spectra, representative of landscape types in the Selenga catchment. As shown earlier (BDP Members, 2005), palynological spectra in BDP-99 are among the most representative among the Baikal sites: the sediments contain pollen of arboreal species not easily transported by wind (e.g. Picea, Abies) and those tending to be poorly preserved (e.g. Larix) (Bezrukova, 1998).
Similar to other records in Eurasia, past interglacials in the Lake Baikal region were characterized by the expansion of forests. Around Baikal, dense boreal forests (taiga) consist of spruce, Siberian pine, fir, Scots pine; while birch and larch are typical in more open forest-steppe landscapes. The palynological signals of past interglacials in the continuous Baikal records are thus fully compatible with palynological signatures from discontinuous sections in the formerly glaciated adjacent and more distant regions of Eurasia. The composition of pollen may be quantified into the likely climatic characteristics (temperatures of warm/cold seasons, annual precipitation) using quantitative method of biome reconstruction (Prentice et al., 1996) and modern analog techniques. So far, this has been done for the last interglacial (Tarasov et al., 2005) and for the Holocene (Tarasov et al., 2007). In this study we present the first quantitative reconstruction of the annual precipitation and temperature anomalies derived from the BDP-99 pollen record representing interglacial conditions in the Lake Baikal region during MIS 11 and its comparison with MIS 1 (Holocene) climate.

Here we use the Lake Baikal record to pursue two main objectives: (1) discuss the duration and orbital signature of MIS 11 interglacial in the largest continental interior on earth, and (2) discuss the climatic signature of the MIS 11 interglacial based on comparing lacustrine proxy records and sediment mineralogy with the first detailed MIS 11 palynological record and pollen-based reconstructions of regional climate. The apparent duration of MIS 11 has been discussed previously in a single BDP-96 record based on past changes in diatom productivity and biogenic silica accumulation (Prokopenko et al., 2001a; Karabanov et al., 2003; Mackay et al., 2008). By comparing prior results with the new MIS 11 pollen record, here test the extent to which the MIS 11 diatom/BioSi peak actually represents true interglacial conditions in the region. We also cross-check prior estimates of the apparent duration of the MIS 11 interglacial in contrasting depositional settings in the Lake Baikal basin and show that the apparent exceptional duration of the MIS 11 interglacial is not an artifact of an age model construction in a single record. Then we discuss which part of the MIS 11 interval (if any) may be regarded as a climatic analog of the Holocene. In addition to biological proxies for terrestrial vegetation and lake primary productivity we for the first time employ proxies for past changes in the weathering conditions in the Baikal watershed.

\section{Methods}

Diatoms in the new BDP-99 record of the MIS 11 interval were quantitatively counted using a technique described by Khursevich et al. (2001); these results are used for biostratigraphic correlation with the diatom record from BDP96-2 drill core (ibid.). Diatom specimens were examined by oil immersion light microscopy $(\times 1000$ magnification) using an Ergaval microscope with a $100 \times$ objective $(\mathrm{NA}=1.25)$. 
Samples for palynological analysis $\left(1-1.5 \mathrm{~cm}^{3}\right.$ of wet sediment) were processed using standard $\mathrm{HCl}$ and $\mathrm{KOH}$ treatments, heavy-liquid separation and acetolysis (Berglund and Ralska-Jasiewiczowa, 1986). Pollen and spores mounted in silicon oil were studied in light microscope Olympus X320c at $\times 400-1000$ magnification; for taxonomic identification we used the permanent collection in the Institute of the Earth Crust (Irkutsk, Russia) and regional atlases. Up to 800-1200 palynomorphs were counted in the lower part of the studied BDP-99 interval (64.8 and $62.7 \mathrm{~m}$ ); in the upper part between 62.7 and $59.5 \mathrm{~m}$ pollen abundance was relatively low (260460 counted grains). Percentages for individual taxa were estimated from the total pollen sum (AP and NAP, excluding Polypodiaceae, Selaginella, Lycopodiaceae, Sphagnum, and Equisetum). Pollen zone boundaries were distinguished visually. The steppe/forest index (SFI) (Traverse, 1988) was adapted to visualize overall changes of landscapes. Because Ephedra and Caryophyllaceae are typical members of steppe association in the Baikal region, the modified version of the SFI index was calculated as ratio of the pollen sum of Artemisia, Chenopodiaceae, Ephedra and Caryophyllaceae to the pollen sum of the above group and tree pollen, multiplied by 100 .

For CHN and stable isotope analysis, dried sediment was homogenized in an agate mortar, decalcified with $5 \% \mathrm{HCl}$ in an ultrasonic bath for ca. $45 \mathrm{~min}$ at room temperature, repeatedly washed with deionized water, centrifuged at $3000 \mathrm{rpm}$, and dried at $50^{\circ} \mathrm{C}$. Ground 6- to $12-\mathrm{mg}$ samples were analyzed using a VG Optima mass spectrometer interfaced with a Carlo-Erba NC 1500 Elemental Analyzer for simultaneous carbon and nitrogen measurements. Carbon stable isotope ratios are reported as \%o PDB.

Sediment mineralogy was studied in bulk non-fractionated samples; in order to identify clay minerals (including the mixed-layer phases), the complete experimental X-Ray Diffraction (XRD) patterns were modeled. The details of sample preparation techniques, modeling algorithm and application of these methods are given by Solotchina et al. (2002, 2009) and Solotchina (2009). XRD patterns were obtained using DRON automated powder diffractometer system with $\mathrm{Cu} \mathrm{K}_{\alpha}$ radiation, graphite monochromator. Scans were performed for modeling from $2^{\circ}$ to $35^{\circ} 2 \theta$ with speed of $0.05^{\circ} 2 \theta / \mathrm{s}$ and a counting time of $32 \mathrm{~s}$, for the phase analysis from $2^{\circ}$ to $65^{\circ} 2 \Theta$ with the same speed but with a counting time of $3 \mathrm{~s}$. Infrared (IR) spectroscopy was used to determine the contents of feldspar, quartz and amorphous biogenic silica, estimated from the IR transmission spectra recorded on a Specord 75 IR double-beam spectrophotometer in the frequency region $400-4000 \mathrm{~cm}^{-1}$.

The modern analogue approach was applied earlier to the pollen records from Lake Baikal in order to reconstruct climate during the Eemian (MIS 5e) interglacial and the Holocene (Tarasov et al., 2005, 2007). To reconstruct annual precipitation $\left(P_{\mathrm{ann}}\right)$ and annual temperature anomalies $\left(T_{\mathrm{w}}-T_{\mathrm{c}}\right)$, calculated as mean temperatures of warmest month minus mean temperature of coldest month, in the present study we used the reference data set of 1173 modern pollen spectra representing all main bioclimatic regions from northern Eurasia. Reconstructed climatic variables are helpful for understanding changes in the regional vegetation and climate during the MIS 11 interglacial and for comparison with the qualitative climate interpretations derived from the other proxies in our study. All terrestrial pollen taxa identified in the BDP-99 record also appear in the list of 81 taxa presented in the reference pollen/climate data set. Modern climate values at each of the 1173 modern pollen sampling sites have been calculated from the highresolution global climatology database that provides the 30 year average (1961-1990) of the monthly means of principal meteorological parameters on a $10 \mathrm{~min}$ grid (see Tarasov et al., 2005 for details and references).

\section{Age model and glacial-interglacial cycles in the Baikal record}

The age-depth relationship of the Lake Baikal sedimentary records of the mid-late Pleistocene is best established for the Academician Ridge area, which as a bathymetric high not influenced by either riverine input or turbidite deposition (Fig. 2). As shown by paleomagnetic event/reversal time scales of the BDP-96 and BDP-98 drill core records retrieved in 320-330 $\mathrm{m}$ water depth, Pleistocene sedimentation rates in this area remained remarkably stable at ca. $4 \pm 2 \mathrm{~cm} / \mathrm{kyr}$ (BDP Members, 1997; 2001). The relative stability of sedimentation rates in this area is independently confirmed by radiocarbon dating (Colman et al., 1996; Nakamura et al., 2003) and magnetic paleointensity age models of the late Pleistocene (Peck et al., 1996; Demory et al., 2005). Because of the dramatic variations in Lake Baikal diatom production in response to climate, the Pleistocene glacial-interglacial cycles at Academician Ridge are represented by a distinct pattern of variations in biogenic silica content (BioSi) in sediments. In warm (interglacial) intervals BioSi constitutes up to $40-50 \%$ dry sediment weight, in cold intervals diatoms (and hence $\mathrm{BioSi}$ ) are not present in sediments. Interstadial intervals appear in the Baikal record as low- or intermediate-amplitude BioSi peaks (Prokopenko et al., 2001a).

The orbitally-tuned age models for the Lake Baikal records were based on assigning the age tie points to BioSi peaks. Location in high latitudes and in the largest continental interior on Earth makes coupled lake-watershed system highly sensitive to both obliquity and precession components of orbital forcing: essentially, every precessional cycle of the Brunhes chron may be recognized in the Baikal lacustrine proxy records from the Academician Ridge. Since the original peak-to-peak correlations of the BDP-96-2 BioSi record with ODP-677 (Williams et al., 1997) the age model has evolved. First, $65^{\circ} \mathrm{N}$ June insolation was used as a tuning target for the "most rapid transitions" in BioSi response 


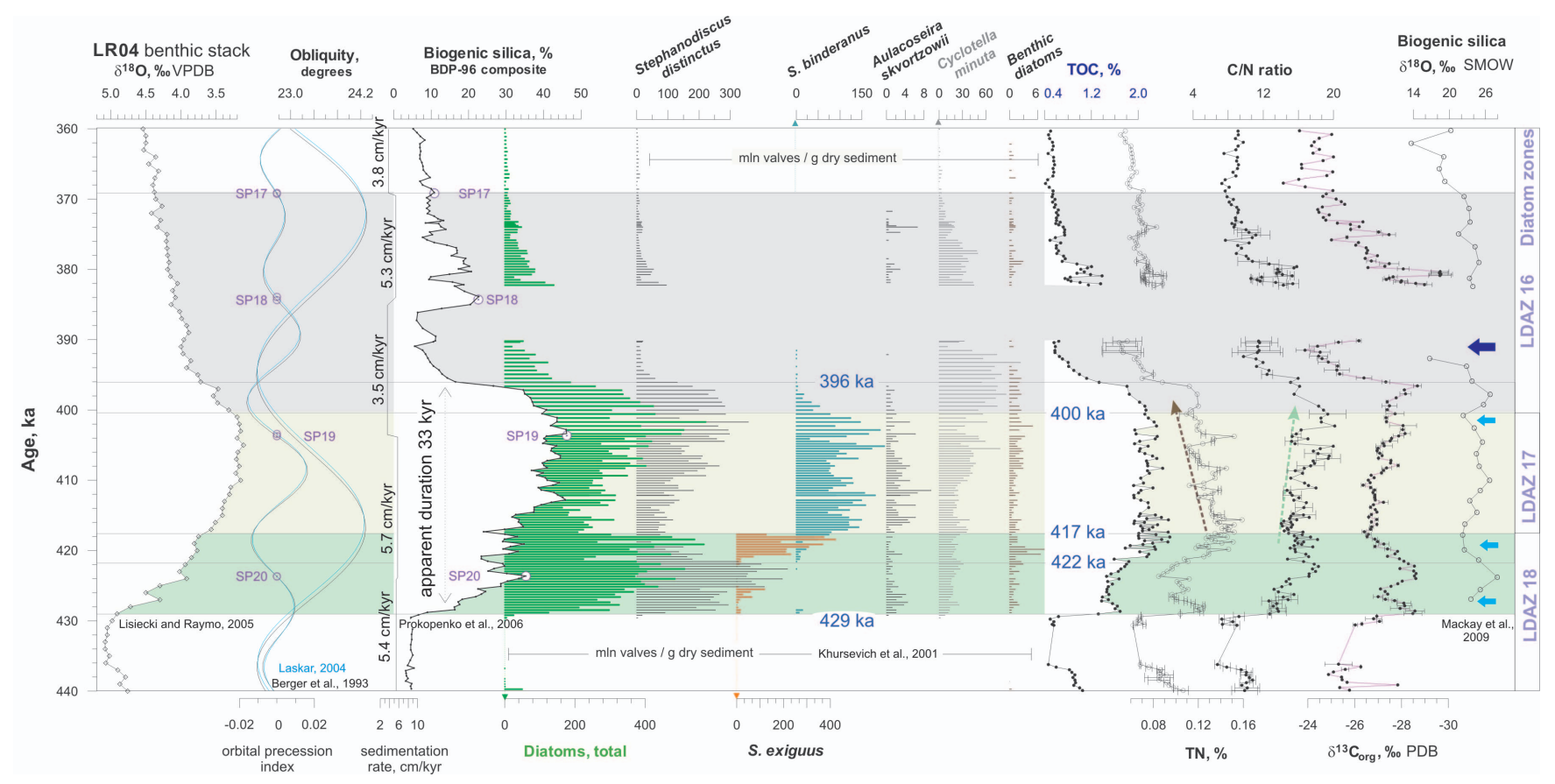

Fig. 3. Lake Baikal productivity proxy records (this study) and diatom biostratigraphy of the holostratotype section BDP-96-2 (Khursevich et al., 2001) plotted to the orbitally-tuned timescale constructed by assigning the September Perihelia (SP) timing to biogenic silica peaks (Prokopenko et al., 2006). The tuned ages of the major biostratigraphic boundaries (horizontal lines) are used as age control points in the BDP-99 record in the following figures. Note the precessional two-peak structure in the Lake Baikal diatom record and the agreement of the independent Baikal age model for the MIS 11 interglacial with the LR04 age model. Orbital parameter solutions are from Berger et al. (1993) and Laskar et al. (2004). The $\delta^{18} \mathrm{O}$ of Baikal diatoms (Mackay et al., 2008) records the cooling at the end of the MIS 11 interglacial (purple arrow), and, possibly, earlier, less significant cooling episodes (blue arrows).

(Prokopenko et al., 2001a). This age model was used in the previous Baikal MIS 11 studies (Karabanov et al., 2003; Mackay et al., 2008), where the age of the MIS 11 interglacial was estimated as 426-395 ka. Later, an alternative orbital tuning was suggested based on assigning September perihelia timing to the BioSi peaks in a composite BDP96 records spliced from parallel twin drill cores BDP-961 and BDP-96-2 (Prokopenko et al., 2006). This approach is more consistent with the observed timing of the BioSi response around independently-dated boundaries (including the Holocene, the last interglacial, top Jaramillo paleomagnetic reversal - see discussion in Prokopenko et al., 2006). Here we use this latest version of the BDP-96 age model; the age of the MIS 11 interglacial interval in the updated age model is 429-396 ka.

The compatibility of the Baikal MIS 11 age model with those of other global records is illustrated by the comparison with LR04 marine oxygen isotope stack in Fig. 3: even though no specific adjustments were attempted to match the records, the alignment of the independent LR04 and Baikal age models is quite remarkable. The close agreement between Baikal diatom silica in the middle of the largest landmass and marine oxygen isotope profiles with regard to a number of interglacial peaks in proxy records, peak amplitudes and even shapes has become evident since the first studies of the Baikal record (Colman et al., 1995; Williams et al., 1997). This sustained match through series of the Pleistocene climatic cycles reflects the large scale of climatic processes which shaped climates of past interglacials. Sensitivity to climate changes on both orbital and suborbital scales in the Baikal BioSi/diatom records points to a significant role of atmospheric circulation processes linking marine and terrestrial records.

Establishing the age control points for the new BDP-99 record required an approach different from that used for the BDP-96 record. BDP-99 site is located in $200 \mathrm{~m}$ water depth in vicinity of the delta of Selenga River, the major tributary of the lake (Fig. 2). As shown previously (BDP Members, 2005), sedimentation rates at this site were changing by a factor of 2-4 with glacial-interglacial transitions. To avoid potential age errors due to variable sediment accumulation rates, we made no effort to independently orbitally-tune the BDP-99 record in this study. Instead, we chose to link two MIS 11 records from Lake Baikal using diatom biostratigraphy. This is possible because several significant changes in the species composition of the dominant planktonic diatom flora have been noted in the MIS 11 interval of the BDP-962 drill core (Khursevich et al., 2001; Karabanov et al., 2003). In order to link the new MIS 11 record from the BDP-99 drill core with the orbitally-tuned age model of the BDP-96 
Table 1. Thicknesses of the interglacial/interstadial intervals of three interglacial cycles at BDP-96 and BDP-99 drill sites in Lake Baikal, and the apparent sedimentation rates.

\begin{tabular}{|c|c|c|c|c|c|c|c|c|}
\hline \multirow[b]{2}{*}{$\begin{array}{l}\text { Drill } \\
\text { core } \\
\text { (site) }\end{array}$} & \multirow[b]{2}{*}{$\begin{array}{l}\text { MIS } \\
\text { substage } \\
\text { in Baikal } \\
\text { record }^{1,2}\end{array}$} & \multirow[b]{2}{*}{$\begin{array}{l}\text { Duration } \\
\text { (orbital } \\
\text { model) } \\
\text { kyr }\end{array}$} & \multicolumn{5}{|c|}{ Thickness of intervals in parallel proxy records, $\mathrm{cm}$} & \multirow[b]{2}{*}{$\begin{array}{l}\text { Sed. } \\
\text { rate } \\
\mathrm{cm} / \mathrm{kyr}\end{array}$} \\
\hline & & & $\begin{array}{l}\text { biogenic } \\
\text { silica } \\
\text { record }^{2}\end{array}$ & $\begin{array}{l}\text { quantitative } \\
\text { diatom } \\
\text { abundance }\end{array}$ & $\begin{array}{l}\text { semi- }^{-} \\
\text {quantitative } \\
\text { diatom } \\
\text { abundance }^{7}\end{array}$ & $\begin{array}{l}\text { arboreal } \\
\text { pollen } \\
\text { record }^{4}\end{array}$ & $\begin{array}{l}\text { Ratio of } \\
\text { thickness } \\
\text { in pollen } \\
\text { vs diatom } \\
\text { records }\end{array}$ & \\
\hline \multirow{13}{*}{ 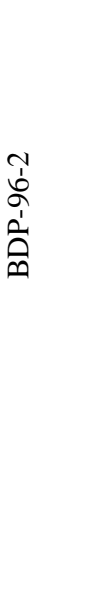 } & $5 \mathrm{a}$ & $14 \mathrm{kyr}$ & $68 \mathrm{~cm}$ & $74 \mathrm{~cm}$ & - & - & - & 4.9 \\
\hline & $5 c$ & $12 \mathrm{kyr}$ & $62 \mathrm{~cm}$ & $70 \mathrm{~cm}$ & - & - & - & 5.2 \\
\hline & $5 e$ & $13 \mathrm{kyr}$ & $73 \mathrm{~cm}$ & $77 \mathrm{~cm}$ & - & $54 \mathrm{~cm}$ & $74 \%$ & 5.6 \\
\hline & $5 e^{*}$ & $11 \mathrm{kyr}^{5}$ & - & $106, \mathrm{~cm}^{5}$ & - & $97 \mathrm{~cm}^{6}$ & $* 92 \%$ & 9.6 \\
\hline & $7 \mathrm{a}$ & $14 \mathrm{kyr}$ & $60 \mathrm{~cm}$ & $64 \mathrm{~cm}$ & - & $34 \mathrm{~cm}$ & $57 \%$ & 4.3 \\
\hline & $7 \mathrm{c}$ & $10 \mathrm{kyr}$ & $52 \mathrm{~cm}$ & $52 \mathrm{~cm}$ & - & $33 \mathrm{~cm}$ & $64 \%$ & 5.2 \\
\hline & $7 \mathrm{e}$ & $10 \mathrm{kyr}$ & $54 \mathrm{~cm}$ & $56 \mathrm{~cm}$ & - & $35 \mathrm{~cm}$ & $65 \%$ & 5.4 \\
\hline & $7 a+b+c$ & $34 \mathrm{kyr}$ & $150 \mathrm{~cm}$ & $150 \mathrm{~cm}$ & - & $119 \mathrm{~cm}$ & $79 \%$ & 4.4 \\
\hline & $9 \mathrm{c}$ & $10 \mathrm{kyr}$ & $52 \mathrm{~cm}$ & $48 \mathrm{~cm}$ & - & - & - & 5.2 \\
\hline & $9 \mathrm{e}$ & $13 \mathrm{kyr}$ & $66 \mathrm{~cm}$ & $83 \mathrm{~cm}$ & - & - & - & 5.1 \\
\hline & $9 e+d+c$ & $29 \mathrm{kyr}$ & $149 \mathrm{~cm}$ & $157 \mathrm{~cm}$ & - & $\sim 100 \mathrm{~cm}$ & $67 \%$ & 5.1 \\
\hline & & & & & & & $68 \pm 8 \%$ & \\
\hline & MIS 11 & $33 \mathrm{kyr}$ & $166 \mathrm{~cm}$ & $174 \mathrm{~cm}$ & - & - & - & 5.0 \\
\hline \multirow{12}{*}{$\begin{array}{l}2 \\
\text { à } \\
\text { के }\end{array}$} & $5 a$ & $14 \mathrm{kyr}$ & - & - & $137 \mathrm{~cm}$ & $133 \mathrm{~cm}$ & $97 \%$ & 9.8 \\
\hline & $5 c$ & $12 \mathrm{kyr}$ & - & - & $159 \mathrm{~cm}$ & $154 \mathrm{~cm}$ & $97 \%$ & 14.5 \\
\hline & $5 e$ & $13 \mathrm{kyr}$ & - & - & $153 \mathrm{~cm}$ & $146 \mathrm{~cm}$ & $95 \%$ & 11.8 \\
\hline & $7 \mathrm{a}$ & $14 \mathrm{kyr}$ & - & - & - & $127 \mathrm{~cm}$ & - & - \\
\hline & $7 \mathrm{c}$ & $10 \mathrm{kyr}$ & - & - & - & $100 \mathrm{~cm}$ & - & - \\
\hline & $7 \mathrm{e}$ & $10 \mathrm{kyr}$ & - & - & $122 \mathrm{~cm}$ & $120 \mathrm{~cm}$ & $98 \%$ & 12.2 \\
\hline & $7 a+b+c$ & $34 \mathrm{kyr}$ & - & - & $279 \mathrm{~cm}$ & $273 \mathrm{~cm}$ & $102 \%$ & 8.2 \\
\hline & $9 \mathrm{c}$ & $10 \mathrm{kyr}$ & - & - & $92 \mathrm{~cm}$ & $87 \mathrm{~cm}$ & $95 \%$ & 8 \\
\hline & $9 \mathrm{e}$ & $13 \mathrm{kyr}$ & - & - & $97 \mathrm{~cm}$ & $94 \mathrm{~cm}$ & $97 \%$ & 7.5 \\
\hline & $9 e+d+c$ & $29 \mathrm{kyr}$ & - & - & $254 \mathrm{~cm}$ & $253 \mathrm{~cm}$ & $100 \%$ & 8.8 \\
\hline & & & & & & & $97 \pm 2 \%$ & \\
\hline & MIS 11 & $33 \mathrm{kyr}$ & - & $>284 \mathrm{~cm}$ & $>284 \mathrm{~cm}$ & $>284 \mathrm{~cm}$ & - & $>8.6$ \\
\hline
\end{tabular}

* The estimated duration of the Lake Baikal equivalent of MIS 5e interglacial in core CON01-603-2 is based on paleointensity tie points. Sedimentation rates in BDP-96-2 are estimated from BioSi record. Sources for estimates of duration and thickness:

${ }^{1}$ Prokopenko et al. (2001a); ${ }^{2}$ Prokopenko et al. (2006); ${ }^{3}$ Khursevich et al. (2001); ${ }^{4}$ Shichi et al. (2007);

${ }^{5}$ Rioual and Mackay (2005); ${ }^{6}$ Granoszewski et al. (2005); ${ }^{7}$ BDP Members (2005).

composite record from a more stable depositional setting we first studied the diatom record of the BDP-99 section and identified the same diatom biostratigraphic boundaries as those observed in the BDP-96-2 section (245 km NE, Fig. 2). Then we assigned the orbitally-tuned ages of these respective boundaries (as established based on the BDP-96 composite record) to the new BDP-99 record as a safer way of constructing the MIS 11 age model of BDP-99 (see below).

The "Lake Baikal MIS 11 interglacial" corresponds to the marine isotopic substage 11c (containing marine isotopic event 11.3) in the taxonomy of marine oxygen isotope stages (e.g. Prell et al., 1986). It is important to note, however, that unlike the younger substages MIS $9 \mathrm{c}, 7 \mathrm{c}, 5 \mathrm{c}$, etc., which correspond to single respective peaks of orbital precession, the marine substage designated "MIS $11 \mathrm{c}$ " corresponds to two peaks of precession index coincident with an obliquity maximum (Fig. 3). The observed structure of the Baikal proxy records (Fig. 3) and the extended duration of this interglacial (Table 1) are consistent with this orbital configuration. The end of the "Lake Baikal MIS 11 interglacial" at ca. 396 ka corresponds to marine isotopic event 11.2 (within marine isotopic substage 11b). 


\section{The apparent duration of the MIS 11 in the Lake Baikal record}

One of the remarkable features of the MIS 11 interglacial is the extended ca. 30-kyr duration (e.g. McManus et al., 2003): in most age models this warm interval is nearly twice as long as the last interglacial. Our previous age models also suggested the ca. 32-kyr duration (e.g. Karabanov et al., 2003). Here we corroborate our prior model using new Baikal data. Table 1 compares the apparent duration of the past three interglacial intervals at two Lake Baikal sites $245 \mathrm{~km}$ apart, which represent contrasting depositional settings. As seen in the Table, the average sedimentation rates during interglacials and interstadials remained relatively stable at each of the drill sites, being consistently higher at the BDP-99 site. The thickness of the MIS 11 interglacial intervals in both drill cores is at least twice that of the last interglacial interval; the thickness of the MIS 11 interval is similar to the thicknesses of the combined MIS 9e-d-c and MIS 7c-b-a intervals (each corresponding to two precessional cycles). Thus the comparison of thickness of respective interglacial intervals (Table 1) corroborates the assignment of the MIS 11 interglacial interval in the Baikal record to two precessional cycles in the orbitally-tuned age models (Prokopenko et al., 2001a; 2006).

Estimating the duration of past interglacials in continental Eurasia based on BioSi/diatoms in a lake may be questioned as being of limited use, because this is not how interglacials are typically identified in continental records elsewhere. In addition, because the ecology of the (mostly endemic) Baikal diatoms is not well established, the observed changes in diatom abundance and species composition during past interglacial cycles do not readily translate into climatic parameters (e.g. seasonal temperatures). To answer this potential concern, Table 1 makes a comparison of the apparent durations of past interglacials and interstadials in the Baikal record as estimated from conventional palynological proxies and from the $\mathrm{BioSi} /$ diatom proxies.

Table 1 shows that productive diatom flora expanded in the lake at the time of the expansion of forests in the Baikal region. Previously, the close temporal relationship between BioSi/diatom and arboreal pollen proxies for warm regional climate has been established for the radiocarbondated Holocene interval (e.g. Prokopenko et al., 2007) and for the paleointensity-dated last interglacial interval, as seen from the comparison of diatom (Rioual and Mackay, 2005) and pollen (Granoszewski et al. 2005) records. For older interglacial and interstadial intervals, the apparent durations (thicknesses) agree in pollen and BioSi/diatom records as well (Table 1). For instance, the close agreement is evident in the well-resolved BDP-99 record, where thicknesses of interglacial intervals estimated independently from pollen composition (Shichi et al., 2007) nearly coincide with those estimated from core lithology (BDP Members, 2005) to within $97 \pm 2 \%$. By contrast, in the BDP-96 record, intervals rich in arboreal pollen appear systematically shorter (thinner,
$68 \pm 8 \%$ ) as compared with the estimates based on the BioSi record (Table 1). This seeming discrepancy is mainly due to the different resolution of the records: BioSi and diatoms were studied at $1-2 \mathrm{~cm}$ resolution, whereas pollen was studied at low ca. $10 \mathrm{~cm}$ resolution (5-7 samples per warm interval). In addition, because of the location distant from sources of terrigenous input, BDP-96 sediments are not rich in pollen, making palynological records less representative. In the better-resolved record CON01-603-2 in $386 \mathrm{~m}$ water depth from the same general area (Fig. 2) the duration (thickness) of the last interglacial interval estimated in diatom and in pollen records nearly coincide (Table 1 , MIS 5e*).

The following conclusions are the most relevant to justifying the Lake Baikal age model for the MIS 11 interglacial: (1) regardless of the depositional setting, MIS 11 is the longest/thickest among the last four interglacial intervals, both at Academician Ridge (BDP-96) and in Selenga Delta area (BDP-99); (2) Lake Baikal BioSi is a reliable index of past interglacials in continental interior Asia: durations of the intervals of high BioSi production (accumulation) match the duration of regional forest phases, as seen in the bestresolved records; (3) neither lithology nor sedimentation rate estimates indicate accumulation rate anomalies during MIS 11 at the BDP drill sites. Thus, the increased thickness of the MIS 11 interglacial interval in the Baikal record is a true reflection of an unusual extended duration of this interglacial in continental Eurasia.

\section{The new diatom record of the MIS 11 interval from the BDP-99 drill core}

The total diatom abundance during MIS 11 in BDP-99 is about half that in BDP-96-2 (Fig. 4), which is consistent with differences in average sedimentation rates (Table 1) and thus with the degree of dilution of biogenic component in sediments with clastic component. The overall two-peak structure of the diatom abundance profile in BDP-99 is similar to that in BDP-96-2 (Fig. 3). Dominant species in the lower part of the BDP-99 record below $6360 \mathrm{~cm}$ are Stephanodiscus distinctus var. distinctus and S. exiguus (Fig. 4). Co-occurrence of these species is characteristic of local diatom assemblage zone (LDAZ) 18 in the BDP-96-2 holostratotype section (Fig. 3; Khursevich et al., 2001). At ca. $6340 \mathrm{~cm}$ in BDP-99, a rapid increase in the abundance of $S$. binderanus and the decline of S. exiguus are observed (Fig. 4). The same change in the diatom assemblage composition was previously observed in BDP-96-2 and recognized as LDAZ 18/17 biostratigraphic boundary at ca. $417 \mathrm{ka}$ (Fig. 3). Above $6120 \mathrm{~cm}$ in the BDP-99 record, S. binderanus disappears from diatom assemblage at a time of substantial increase in the abundance of Cyclotella minuta (Fig. 4). A similar change in the composition of the Baikal diatom assemblage was previously observed in the BDP-96-2 holostratotype as well, where it was recognized as LDAZ 17/16 biostratigraphic boundary at ca. 400 ka (Fig. 3; Khursevich et al., 2001). 


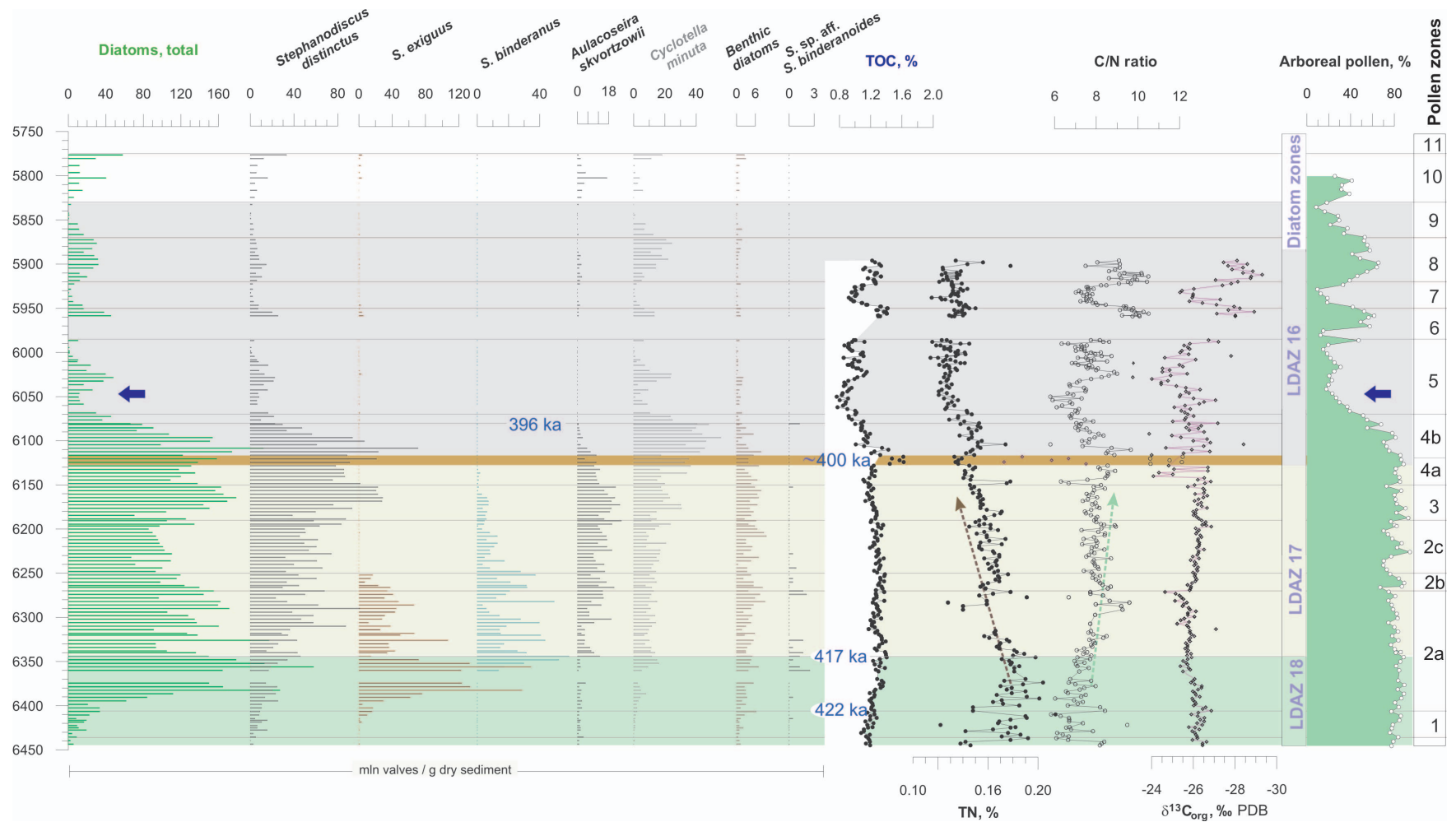

Fig. 4. New records of diatom abundance, species composition and productivity proxies during the MIS 11 interglacial interval in the Lake Baikal BDP-99 drill core plotted to depth in cm. Age control points are assigned based on biostratigraphic correlation with BDP-96-2 (LDAZ boundaries in Fig. 2). The MIS 12/11 transition is believed to not have been recovered in this section. The abundance of arboreal pollen (compare with Fig. 3) underscores the good agreement between lacustrine and terrestrial responses to the onset and the decline of interglacial conditions in the Baikal area. Brown shaded bar marks the interval with anomalous $\delta^{13} \mathrm{C}_{\text {org }}$ and $\mathrm{C} / \mathrm{N}$ signals (see text).

Thus, the relative abundance and the succession of codominant planktonic species in the new detailed diatom BDP-99 record of the MIS 11 interglacial are essentially the same as those in the holostratotype BDP-96-2 section $245 \mathrm{~km}$ NE. It is therefore possible to distinguish the same diatom zones and the respective biostratigraphic boundaries in both records.

The slight differences between BDP-99 and BDP-96-2 biostratigraphic records include (1) the continued presence of Stephanodiscus exiguus in BDP-99 above the LDAZ 18/17 boundary, and (2) the decline in the abundance of $S$. binderanus in the second half of the LDAZ 17 interval in BDP99 (6250-6130 cm, Fig. 4). In addition, a new finding with regard to the composition of diatom assemblage is that individual specimens of Stephanodiscus sp. aff. S. binderanoides were observed in several horizons of the MIS 11 interval (Fig. 4). Previously, this taxon typical of LDAZ 19 (late MIS 12 glacial), was believed to not be present in the Baikal record above the MIS 12/11 transition (Khursevich et al., 2001). In the BDP-96-2 holostratotype section, a relatively low yet still notable abundance of Synedra acus var. radians (up to $15 \mathrm{mln}$ valves/g sediment) has been observed (Khursevich et al., 2001). Apparently, valves of this taxon were not preserved in sediments at the BDP-99 site.
The establishment of the robust biostratigraphic correlation ties within the MIS 11 interglacial intervals of two Lake Baikal drill cores allows putting both records on the same orbitally-tuned timescale using LDAZ boundaries at $400 \mathrm{ka}$, $417 \mathrm{ka}$ and the biostratigraphic change at $422 \mathrm{ka}$ (S. exiguus expansion) as tie points (Figs. 3, 4). This correlation suggests that the earliest portion of the Lake Baikal MIS 11 interglacial (ca. 429-424 ka in BDP-96-2, Fig. 3) was not recovered at the BDP-99 site (Fig. 4). As shown below, this conclusion is consistent with palynological record and with organic matter-based productivity proxy signals.

\section{Productivity proxy records of MIS 11 interglacial in Lake Baikal}

The new productivity proxy records on bulk sedimentary organic matter during MIS 11 from BDP-99 and BDP-96-2 sites include total organic carbon (TOC), total nitrogen (TN), TOC/TN weight ratio $(\mathrm{C} / \mathrm{N})$ and $\delta^{13} \mathrm{C}_{\text {org }}$ ratios. These proxies at both sites are consistent with BioSi/diatom responses in indicating a prolonged interval of high primary production and accumulation of organic matter $(\mathrm{OM})$ in the lake. By analogy with Holocene (TOC 1-3\% dry sediment weight, 
Prokopenko et al., 1999, 2007) and the last interglacial (TOC 1.5-2\%, Prokopenko and Williams, 2003), sustained high OM accumulation during MIS 11 (TOC 1-2\%, Figs. 3, 4) may be interpreted as an indication of high lake productivity characteristic of "full-scale" interglacial conditions, not unlike those during MIS 1 and MIS 5e intervals. At the BDP96 site, the structures and the trends in productivity proxy records are much stronger pronounced (e.g. two-peak structures of diatom and $\delta^{13} \mathrm{C}_{\text {org }}$ profiles in Fig. 3) as compared to those at the BDP-99 site (Fig. 4), where the MIS 11 profiles of TOC and $\delta^{13} \mathrm{C}_{\text {org }}$ are essentially flat. This observation underscores the differences in settings of two drill sites. BDP99 is located in the area of elevated nutrient supply from Selenga River (Fig. 2); primary productivity and organic matter export from the photic zone here remained quite stable throughout the MIS 11. By contrast, proxies at the BDP96 site, which is distant from riverine input (Fig. 2), appear to have recorded stronger changes in productivity and/or organic matter preservation. Higher sedimentation rates (Table 1) at the shallower BDP-99 site (200 m) as compared with those at the BDP-96 (330 m) imply faster settling and burial of primary-produced organic matter. Hence, the effect of grazing and degradation (both within the water column and at sediment/water interface) of the primary-produced OM is possibly less significant at the BDP-99 site.

The observation of low $\mathrm{C} / \mathrm{N}$ ratio in Baikal sediments in vicinity of the major river delta (BDP-99) and high $\mathrm{C} / \mathrm{N}$ at the location distant from terrestrial sources of suspended load (BDP-96) is counterintuitive. This observation lends support to the idea that $\mathrm{C} / \mathrm{N}$ ratio changes at hemipelagic Baikal sites are in large part a reflection of internal carbon cycling mechanisms rather than a measure of a simple mixture of organic matter from two (terrestrial vs. lacustrine) end-member sources (Prokopenko et al., 2009). The lack of close correlation between $\delta^{13} \mathrm{C}_{\text {org }}$ and $\mathrm{C} / \mathrm{N}$ variations is also supportive of this idea.

Without getting into much detail, here we discuss the features of the high-resolution MIS 11 productivity proxy records that make them similar to those of the Holocene (Prokopenko et al., 2007) and the last interglacial (Prokopenko and Williams, 2003). One apparent similarity between all three interglacials is that TOC and TN increases at the onset of interglacials occur more rapidly than the respective increases in BioSi. In addition, in all three cases including the MIS 11 (Fig. 3) the glacial/interglacial transition is associated with a pronounced negative excur-

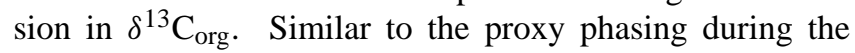
Holocene (Prokopenko et al., 2007), the MIS 11 BioSi maximum lags the TOC maximum (Fig. 3). The apparent decoupling between these productivity signals indicates that algal groups other than diatoms played an important role in the lake's primary production, especially during the early portions of the respective interglacials. This idea is supported by the comparison of the Holocene BioSi content with records of photosynthetic pigments and carotenoids: a significant contributions of $\mathrm{OM}$ from green algae and cyanobacteria was detected at a time of peak TOC accumulation ca. 8-5 ka (Tani et al., 2002), whereas the major BioSi/diatom peak occurred after 4 ka (Prokopenko et al., 2007).

Similar to the $\mathrm{C} / \mathrm{N}$ ratio records of the Holocene and the last interglacial (Prokopenko and Williams, 2003), C/N ratios progressively increased at both BDP sites during the Lake Baikal MIS 11 interglacial (Figs. 3, 4, dashed arrows). This pervasive trend during Baikal interglacials may be viewed as a reflection of increasing efficiency of the lake's "biological pump": progressively higher amounts of carbon per unit nitrogen were sequestered in bottom sediments. Nitrogen sequestration in bottom sediments during the early MIS 11 was higher than in late MIS 11 at both BDP-99 and BDP-96 sites (Figs. 3, 4).

For the purposes of this study it may therefore be concluded that at pelagic sites in Lake Baikal the succession of productivity proxy responses, their relative phasing and general trends in the sedimentary records of MIS 11, MIS 5 and MIS 1 interglacials have a lot in common. Common features testify that the MIS 11 productivity proxy signals in Lake Baikal are not atypical and adequately reflect changes in the cumulative productivity of the coupled lake-watershed system in continental interior Asia.

It is worth noting here that anomalous excursions are observed in TOC, $\mathrm{C} / \mathrm{N}$ and $\delta^{13} \mathrm{C}_{\text {org }}$ in a thin layer 6115$6125 \mathrm{~cm}$ in BDP-99 (Fig. 4, brown shading). An unusual signal of isotopically-heavy bulk sedimentary carbon $(-17$ to $-20 \%$, purple dots in Fig. 4) in this layer is likely due to the presence of detrital carbonates that were not leached out by mild $\mathrm{HCl}$ treatment. Previously, series of similar carbonate(dolomite)-bearing layers with anomalous bulk $\delta^{13} \mathrm{C}$ were observed in the Selenga Delta area sediments at the BDP-93 site (Fig. 2) and were interpreted to represent local erosional events in the watershed. It was hypothesized that the unusual lithologic signature reflects repeated anomalous rainfall events linked to Heinrich events/Bond cycles during the MIS 4-2 interval (Prokopenko et al., 2001b). Even though in the visual description of the BDP-99 drill core the layer $6115-6125 \mathrm{~cm}$ does not stand out macroscopically (BDP Members, 2005), it is possible that the $\mathrm{TOC} / \delta^{13} \mathrm{C}$ signal registered a similar Baikal erosional event toward the end of the MIS 11 interglacial, around $400 \mathrm{ka}$ according to the current age model.

The proposed correlation of BDP-96-2 and BDP-99 based on diatom stratigraphy (Fig. 4) suggests that BDP-99 drill core did not recover the MIS 12/11 transition and the earliest part of the MIS 11; the likely basal age of the recovered MIS 11 interval is ca. 423-424 ka (Fig. 4). This conclusion is consistent with high interglacial-type TOC and TN contents at the base of the section (Fig. 4); furthermore, maximum content of TN at the base of the MIS 11 interval recovered in BDP-99 core is likely correlative with TN maximum in the earlier part of the MIS 11 interval in the BDP-96-2 (ca. 422415 ka, Fig. 2). 


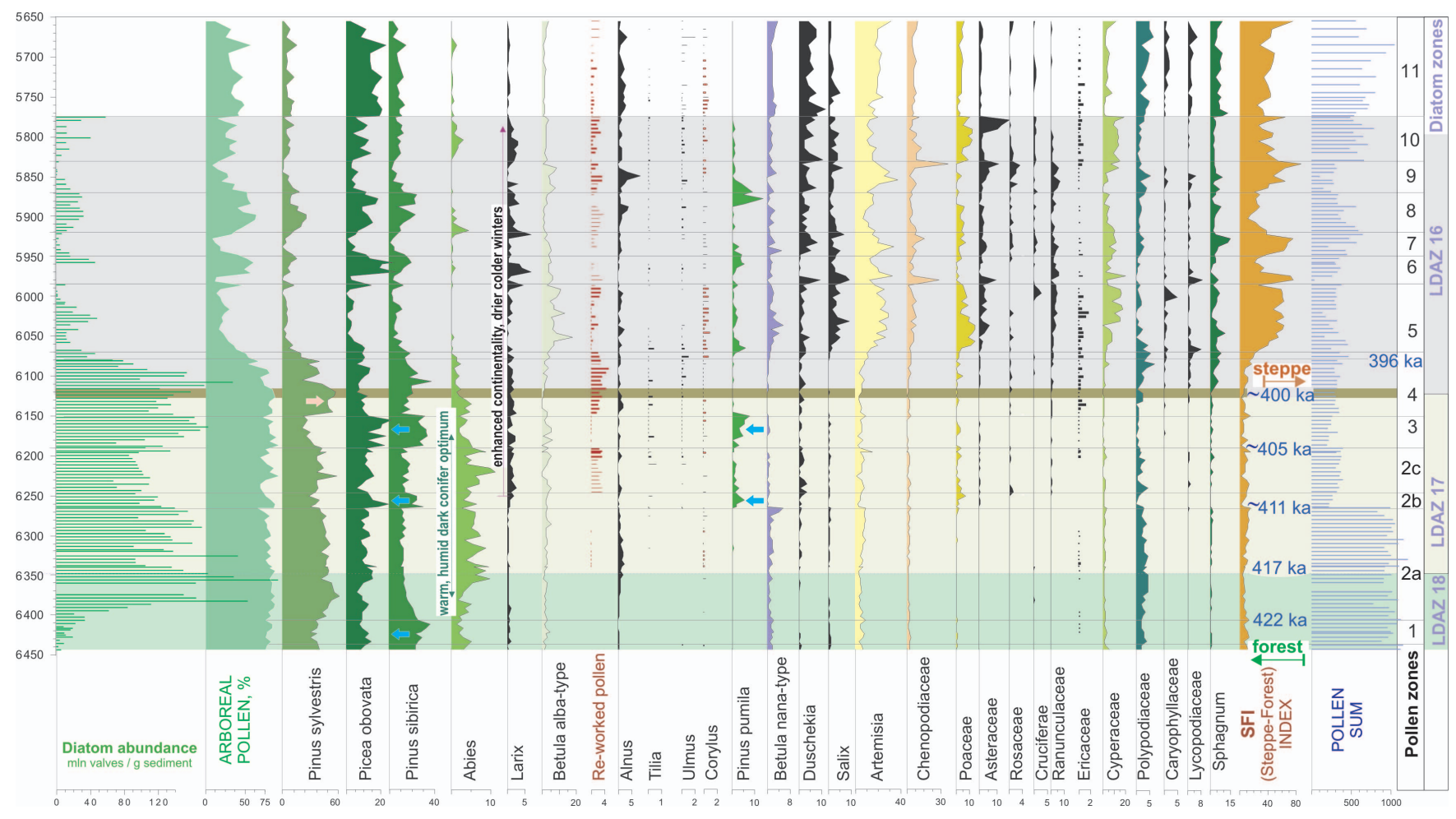

Fig. 5. New palynological record of the MIS 11 interglacial from the Lake Baikal BDP-99 drill core plotted to depth in cm. Age control points are assigned based on diatom biostratigraphic correlation of BDP-99 (LDAZ in Fig. 4) with BDP-96-2 (LDAZ in Fig. 3) Coniferous forest dominated in Lake Baikal region throughout the MIS 11 interglacial until ca. 396 ka (zone 4b); zone 2 represents the prolonged "conifer optimum" indicative of warm snowy winters and temperate humid summers. Repeated cooling episodes (blue arrows) are apparent from changes in the abundance of dominant conifers. Orange arrow marks the expansion of pine in the Baikal region toward the end of the MIS 11 interglacial; a somewhat similar vegetation shift was previously observed in the mid-Holocene record (refer to Fig. 7). Steppe-Forest Index highlights the general change in vegetation type in the Baikal region at the end of the MIS 11 interglacial.

\section{The first high-resolution MIS 11 pollen record from Lake Baikal and pollen-based reconstruction of the interglacial climate}

The new Lake Baikal palynological record of BDP-99 drill core allows visually distinguishing 11 pollen zones (PZ) during the MIS 11-early MIS 10 interval (Fig. 5). Below we discuss zones 1 through 4 , which are characterized by the dominance of boreal conifer (taiga) forest similar to the dominant vegetation type around southern Baikal today, and this is why these zones are of the most direct relevance to reconstructing the MIS 11 interglacial climate in the Baikal region. According to our age model, this period of "full interglacial"-type conifer forest vegetation has lasted continuously for at least 24 kyr.

In PZ 1 at the base of the section, Scots pine (Pinus sylvestris) and Siberian pine (P. sibirica) are dominant, spruce (Picea), fir (Abies), larch (Larix) and birch (Betula alba-type) are present, making the composition of pollen in this interval quite similar to sub-recent pollen spectra. It is therefore likely that regional climate was similar to that of today in a sense of being a climate of a full-scale interglacial.
PZ 2 is characterized by the elevated abundance of Abies (fir) pollen, which is indicative of the expansion of dark coniferous forest. Because fir is particularly sensitive to precipitation and temperatures, today this species has a quite limited distribution around Lake Baikal. High abundance of fir throughout the PZ 2 interval of the Lake Baikal MIS 11 interglacial therefore indicates milder winter temperatures, higher annual precipitation and less continental climate in the region as compared to those of today. This entire zone may thus be viewed as the "climatic optimum" of MIS 11 in continental Siberia, which lasted for at least $15 \mathrm{kyr}$ (Fig. 5).

PZ 2 is divided into a-b-c portions to highlight the significance of palynological signals at $6245-6260 \mathrm{~cm}$ (PZ 2b). The increase in the abundance of Picea, Pinus sibirica, and, importantly, $P$. pumila pollen in this narrow interval indicates a regional cooling with decreased summer temperatures, lowered evapotranspiration and elevated soil moisture levels. The pollen composition of the following PZ 2c is similar to that of PZ 2a (Fig. 5), thereby indicating the return of a warmer "optimum" climate conditions following the shortterm cooling during the PZ $2 \mathrm{~b}$ interval. The relative increase of Larix pollen since PZ 2c onward, however, may be viewed as an indication of strengthening continentality (sesonality) 
of regional climate in the second half of the Lake Baikal MIS 11 interglacial. Zones PZ 1-2a were characterized by elevated abundances of ferns (Polypodiaceae), which are typical of humid dark conifer forests around Lake Baikal.

PZ 3 has the same type of signal as PZ 2b, with increased abundance of Picea, Pinus sibirica and P. pumila pollen (blue arrows, Fig. 5). This interval of a "colder"-type vegetation appears to have lasted longer, though, and hence is distinguished as a separate zone 3. The return of "warmer"-type vegetation with Abies in PZ 4a was associated with a substantial increase in the abundance of Scots pine pollen (orange arrow, Fig. 5). This type of signal may be interpreted as a shift to higher summer temperatures and a reduction in soil moisture; a similar change in vegetation around Lake Baikal at ca. $6 \mathrm{ka}$ was made apparent by the Holocene palynological records (e.g. Demske et al., 2005; Prokopenko et al., 2007).

Zone $4 \mathrm{~b}$ corresponds to the end of the Lake Baikal MIS 11 interglacial as seen from the gradual decline of forest vegetation and the coeval expansion of steppe elements (note the SFI index); at the same time diatom abundance reduces dramatically (Fig. 5). The decline in TOC and TN contents in PZ 4b interval (Fig. 4) occurs in parallel with those of diatoms and forest vegetation. This observation further testifies that Lake Baikal productivity changes (as reflected by either BioSi/diatom or bulk organic matter proxies) are closely related to the climate-driven changes in terrestrial ecosystem (reflected in pollen records) and thus independently serve as reliable indicators of the onset and decline of interglacial climate in continental interior Asia.

Results of the pollen-based quantitative climate reconstruction suggest a rather long period of relatively humid and mild climate in the Baikal region during MIS 11 (see Sect. 12 below for detailed discussion; Fig. 7, bottom panels). Reconstructed annual precipitation sums vary between 550 and $450 \mathrm{~mm}$ during the interglacial interval and exceed modern values in the region by ca. $100 \mathrm{~mm}$ (Tarasov et al., 2007 and references therein). Our temperature reconstruction suggests that climate was characterized by the less pronounced seasonality during the MIS 11 interglacial in comparison to today. A steady increase in the annual temperature amplitude is reconstructed between 417 and $396 \mathrm{ka}$. The decline of interglacial conditions in the region, as suggested by the changes in pollen assemblages, has occurred at ca. $396 \mathrm{ka}$, marked by the onset of drier and more continental climate with annual precipitation around $300 \mathrm{~mm}$, with colder-than-presentwinters and annual temperature amplitude of $40^{\circ} \mathrm{C}$. Comparable climate was reconstructed during the Allerød interstadial phase of the last termination from the pollen record of the Buguldeika Saddle in Lake Baikal (Tarasov et al., 2007).

\section{The promise of millennial-scale climatic signals during the MIS 11 interglacial}

Because abrupt oscillations of climate in future are expected to adversely affect human well-being in future, the issue of climate stability is one of the central questions addressed in studies of past interglacial climates. Because MIS 11 is often regarded our likely "future in the past", the likelihood of climate oscillations during MIS 11 has been addressed repeatedly. For instance, Kukla (2003) cited evidence for two abrupt "pine-birch events" marking substantial and rapid coolings in Europe during MIS 11, lasting several hundred years each. High-resolution MIS 11 records from North Atlantic, however, showed no evidence for similar cooling episodes (McManus et al., 2003). Here we review the existing evidence for millennial-scale oscillations in the Baikal record.

Sampled at high-resolution, Baikal proxy records are known to exhibit millennial-and/or centennial-scale (several data points) departures of measured properties from average interglacial values. Such departures in several single-proxy records were used to infer repeated climatic oscillations in the Baikal region. For instance, attempts were made to establish links between the "1.5-kyr"-cycle in the North Atlantic IRD record and the Lake Baikal Holocene records of uranium isotopes (Goldberg et al., 2005) or diatom abundance and oxygen isotope ratios in biogenic silica $\left(\delta^{18} \mathrm{O}_{\mathrm{BioSi}}\right)$ (Mackay, 2007). Similar repeated events were believed to have been recognized by Mackay (2007) in Lake Baikal diatom abundance and the derived biovolume records of the last interglacial. Lacking the crosscheck from other proxies at multiple sites, these inferences so far remained largely inconclusive.

The MIS 11 interglacial interval in Lake Baikal provides evidence that low-amplitude oscillations in proxy responses may not be random phenomena. For instance, according to Mackay et al. (2008), the decline in oxygen isotope ratios of biogenic silica $\left(\delta^{18} \mathrm{O}_{\mathrm{BioSi}}\right)$ at the end of the MIS 11 interglacial (395-390 ka) represents regional cooling (purple arrow, Fig. 3). This interpretation is consistent with the rapid decline of lake productivity apparent from diatom abundance and productivity proxies (Fig. 3) and with decline of arboreal (conifer forest) vegetation (purple arrow, Figs. 4, 5). By analogy, the earlier, lower-amplitude $\delta^{18} \mathrm{O}_{\mathrm{BioSi}}$ depletions during Lake Baikal MIS 11 interglacial (Fig. 3, blue arrows) may be viewed as possibly representing regional cooling signals as well. The observation that these signals occur at a time of Lake Baikal diatom biostratigraphic changes and the coeval shifts in organic proxy records (in particular, $\delta^{13} \mathrm{C}_{\mathrm{org}}$ ) may not be coincidental (Fig. 3). Likewise, as shown by the BDP-99 record, diatom biostratigraphic changes tend to coincide with pollen zone boundaries, e.g. PZ 1/2, PZ $2 \mathrm{~b} / 2 \mathrm{a}$ and PZ $4 \mathrm{a} / 4 \mathrm{~b}$ boundaries (Fig. 4). These apparent alignments strengthen the case for the significance of Baikal 


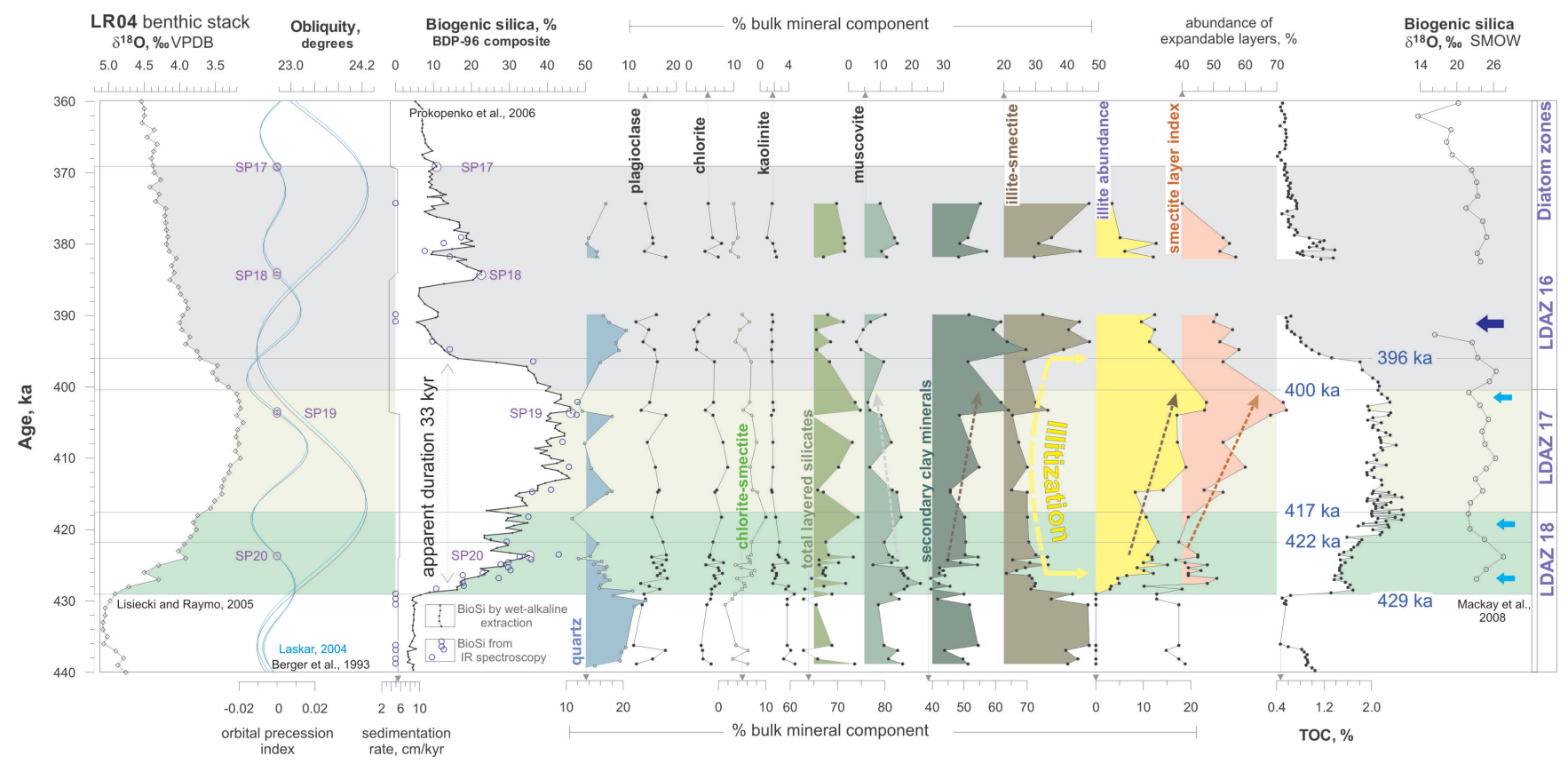

Fig. 6. A new record of the complete composition of the bulk mineral component of the MIS 11 sediments in the BDP-96-2 drill core compared with biogenic silica (Prokopenko et al., 2006) and bulk organic carbon records (this study). The lack of dramatic variability in the abundance of clastic components (quartz, plagioclase, chlorite, muscovite) indicates stable depositional setting in the lake and relative stability of the source area in the watershed. The appearance of illite in Baikal sediments with the onset of MIS 11 interglacial signals active illitization in the watershed: mixed-layer illite-smectite is transformed into illite. Maximum values of illite abundance and smectite layer index are observed at the end of MIS 11; this pattern is similar to the behavior of these indices in mid-late Holocene (see text and Fig. 7). Note that kaolinite is not an index of warmer climate in the Baikal watershed since it behaves as a clastic mineral with maximum abundance during late MIS 12.

proxy responses in representing regional climate changes at sub-Milankovitch resolution.

During the Lake Baikal MIS 11 interglacial, millennialscale changes appear to have been quite subtle since none of these events is clearly recorded in all parallel proxy records. For instance, the most robust Baikal evidence for mid-MIS 11 cooling comes from the new BDP-99 palynological record, in which two cooling episodes in the region are marked by the coeval expansion of Pinus pumila and Pinus sibirica (PZ 2b and PZ3, Fig. 5) at ca. 411-410 and 405$404 \mathrm{ka}$ (also, refer to Fig. 7). Nevertheless, the signatures of these events in diatom abundance, species composition and in productivity-based proxies are not very distinct (zones $2 b$ and 3 in Fig. 4). The significance of the depositional event at ca. $400 \mathrm{ka}$ at the BDP-99 site (Fig. 4, brown shading) is not apparent either: this event, recorded by organic matterbased proxies, is not clearly reflected in diatom (Fig. 4) or pollen (Fig. 5) records. In the BDP-96-2 record, significant oscillations in both BioSi and total diatom abundance are recorded at ca. 422 and $417 \mathrm{ka}$, corresponding to the biostratigraphic boundaries (beginning and the end of peak abundance of Stephanodiscus exiguus) (Fig. 3). The examination of the correlative interval in BDP-99, however, makes it difficult to recognize equivalent signals in palynological record (Fig. 5), in total diatom abundance and/or productivity proxy records (Fig. 4). Even though the studied proxies do not necessarily have equal sensitivity to regional climatic variations, the lack of coeval dramatic variations in proxy responses allows concluding that the MIS 11 interglacial climate in SE Siberia has remained relatively stable.

\section{Sediment mineralogy from XRD analysis and indices of weathering in the Lake Baikal watershed during MIS 11}

Mineralogy of lake sediments, so far understudied in Lake Baikal watershed because of complicated and labor-intensive methodologies, is nevertheless important for developing regional environmental proxies. For instance, production of biogenic silica, a major component of Baikal interglacial sediments, is dependent on the balance of dissolved silica in the lake and is therefore expected to be responsive to climatedriven changes in regional weathering. A recent synthesis of the LGM-Holocene mineralogical records of the neighboring Lake Baikal and Lake Hovsgol basins (Solotchina et al., 2009) helped identifying key regional indices, which represent the effects of climate change on weathering. Here we rely on the conclusions of the cited study in discussing the significance of the MIS 11 mineralogical signatures. 
The analysis of the complete mineral composition of the Lake Baikal MIS 11 interglacial interval in the BDP-962 record in Fig. 6 indicates that this area of lake bottom did not experience dramatic changes in either sediment facies or sources of terrigenous component of the sediments. The lack of dramatic variations in the contents of main clastic components such as quartz, plagioclase, muscovite (Fig. 6) is consistent with the conclusion of a stable depositional setting interpreted from relatively uniform sediment lithology (e.g. Karabanov, 1997; Prokopenko et al., 2001a). The similarities in the basic mineral abundance trends during MIS 11 and MIS 1 (Fig. 7) allow concluding that clastic deposition and weathering of the source material during the MIS 11 was not in any way anomalous when compared with those during the present interglacial.

The key indices representing the relationship between regional climate and weathering in the Baikal watershed (Solotchina et al., 2009) are (1) the abundance of expandable (smectite) layers in illite-smectite (referred to as "smectite layer index" hereafter) and (2) the abundance of illite. The commonsense expectation is that warmer climate promotes formation of secondary clay minerals with expandable (smectite) layers. The high-resolution record of clay mineral composition has shown this to be true in Lake Baikal: the smectite layer index faithfully recorded Bølling-Allerød warming and the Younger Dryas (YD) cooling (Fig. 7). Based on these observations, smectite layer index may be regarded a proxy for enhanced weathering around Lake Baikal during warmer summers. During the MIS 11, the smectite layer index rose steadily and remained quite high during the subsequent MIS 10/11 transition (Fig. 6, pink shading).

The abundance of illite (Fig. 6, yellow shading) is related to weathering as well because illite is known to form from mixed-layer clay minerals through the process called illitization (transformation of mixed-layer silicates into illite). The sensitivity of this index to climate is apparent from the record of the last deglaciation (Fig. 7): illite sensu stricto was absent in sediments of the last glacial at BDP-93 site and first appeared in the Bølling-Allerød interval to disappear again during the YD and the YD-to-early Holocene transition before consistently increasing since ca. $9.5^{14} \mathrm{C}$ ka onward (Solotchina et al., 2009; Fig. 7). The MIS 11 record shows that illitization in the Baikal watershed was also significant during this interglacial. During the late MIS 12, the abundance of mixed-layer illite-smectite is at maximum (Fig. 6, brown shading), whereas illite sensu stricto is not present (Fig. 6, yellow shading). With the onset of Lake Baikal MIS 11 interglacial (as constrained by the coupled diatoms/BioSi and pollen records), the total abundance of the mixed-layer illite-smectite in Baikal sediments becomes a mirror image of the illite abundance, suggesting that illite formed primarily from mixed-layer silicates (Fig. 6).

Both weathering indices in the sedimentary record of BDP-96-2 exhibit a clear trend from minimum values at the beginning of MIS 11 to maximum values at the end of this interglacial (Fig. 6, arrows). The consistent trend toward stronger weathering as suggested by illite abundance and smectite layer index may reflect the overall trend towards maturation and thickening of regional soil profiles, which cumulatively supply increasingly higher amounts of clay minerals as weathering products. A similar trend of continuously increasing illite abundance in the Baikal record from the BDP-93 site (core Ver92/2 GC24, Fig. 2) is observed in the Holocene as well (Fig. 7).

There appears to be a visual similarity between BioSi and illite profiles during the Holocene (Fig. 7) and the MIS 11 (Figs. 6,7). This observation implies a link between weathering as a source of amorphous silica supplied by surface runoff to the lake and the expansion of diatoms as the dominant group of primary producers. New MIS 1 (Fig. 2 in Solotchina et al., 2009) and MIS 11 (Fig. 6) records reveal this apparent relationship for the first time. This linkage may be expected from the balance estimates: presently, as much as $78 \%$ of annual amorphous silica input to the lake via surface runoff is sequestered in bottom sediments (Votintzev, 1961).

The MIS 11 clay mineralogy records make it apparent that illite abundance is closely related to smectite layer index (Fig. 6). A similar close relationship was noted for the record of the past $15 \mathrm{kyr}$ (Solotchina et al., 2009; also, Fig. 7) and is not coincidental. Several factors contribute to this relationship. First, higher abundance of expandable (smectite) layers in illite-smectite results in higher rates of illitization (Bethke and Altaner, 1986). Second, the $42 \%$ smectite layer abundance value is the "magic number": above this threshold the rate of illitization dramatically increases because less fixed potassium is required to transform illite-smectite into illite (Środoñ, et al., 1986). Finally, an important mechanism leading to potassium fixation and hence illtization is the repetition of "wetting-drying cycles" (Eberl et al., 1986). Such cycles also enhance potassium extraction and alteration of bedrock minerals in soils and weathering crusts. These arguments were invoked to explain the differences between clay mineralogy signatures of the early Holocene with cooler and relatively more humid climate and the mid-late Holocene with relatively more arid and more seasonal climate (Solotchina et al., 2009). Applying the same line of argument to the MIS 11 records in Fig. 6, one may conclude that summers during the first half of the Lake Baikal MIS 11 interglacial (ca. 429-414 ka) in continental interior Asia could have been more humid as compared with those of the second half of the Lake Baikal MIS 11 interglacial (ca. 414-396 ka). The implications for changes in effective moisture (humidity) from clay mineralogy proxies (Fig. 6) appear consistent with the implications from terrestrial vegetation changes suggested by the palynological record at PZ 2a/2b boundary (Figs. 5,7 ). 
Holocene

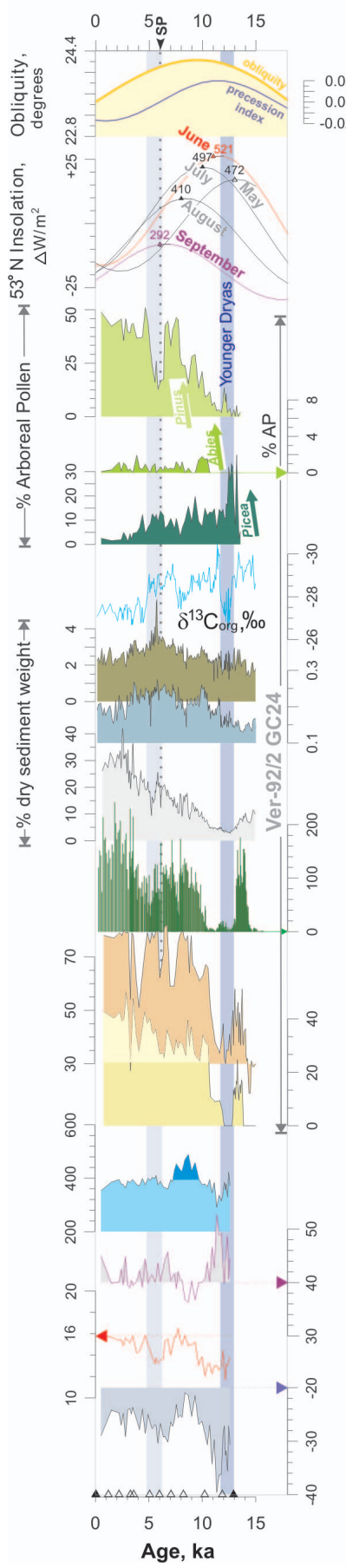

MIS 11

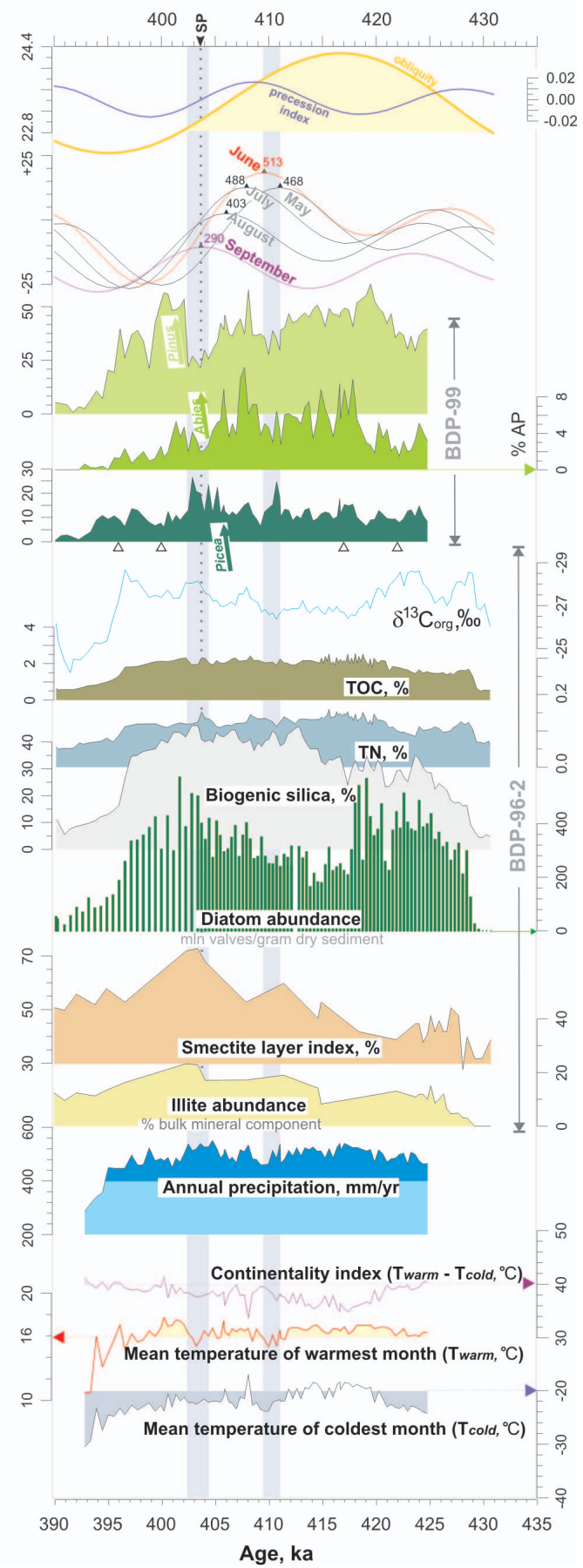

Fig. 7. The synthesis of Lake Baikal proxy records and quantitative reconstructions of climate parameters for MIS 11 interglacial and the Holocene. Orbital configuration and monthly insolation values are from Laskar et al. (2004). Holocene proxy records and age model are from Prokopenko et al. (2007), except for the smectite layer index and illite abundance (Solotchina et al., 2009). The MIS 11 proxy records are from this study, except for biogenic silica content and age model (Prokopenko et al., 2006) and diatom abundance (Khursevich et al., 2001). Arrows highlight somewhat similar vegetation successions (Picea obovata $\rightarrow$ Abies sibirica $\rightarrow$ Pinus sylvestris) during late MIS 11 interglacial and early Holocene. Shading highlights the apparent regional cooling episodes identified in the palynological record. Changes in mean annual precipitation, annual temperature amplitude, mean temperature of warmest month and mean temperature of coldest month for the Holocene (Tarasov et al., 2007) and for the MIS 11 interglacial in the BDP-99 pollen record (this study) were reconstructed using the best modern analogue approach. Data points show the most probable values based on the weighted average of the selected analogues and on the percentages of the sum of terrestrial pollen taxa as defined in Tarasov et al. (2005). 


\section{Comparison of climate of MIS 11 and the Holocene interglacials in the Baikal region}

The potential analogy of climate of the elapsed portion of the Holocene and that of the MIS 11 interglacial has prompted attempts of a direct comparison of the two for the purpose of identifying the likely natural trend of a future climate evolution. For instance, two competing versions of a direct alignment of the Holocene and the MIS 11 records were proposed using Antarctic temperature proxy (EPICA Community Members, 2004, Fig. 5 on p. 626) and orbital parameter configuration (Ruddiman, 2005, Fig. 2 on p. 431). Here we use the Lake Baikal record to make the first direct comparison of (a) qualitative multi-proxy-based paleoclimate signals and (b) quantitative reconstructions of climate during the MIS 11 and the Holocene interglacials in continental setting in the mid-latitudes of the Northern Hemisphere (Fig. 7).

The synthesis of the Holocene and the MIS 11 proxy records in Fig. 7 highlights a number of similarities of interglacial signatures during these intervals: high diatom abundance and contents of biogenic silica, total organic carbon and total nitrogen, the dominance of boreal forest vegetation. Here we focus on the key differences between these interglacials. Perhaps the most pronounced difference in regional vegetation is the sustained important role of Abies sibirica during MIS 11 as compared with that during any part of the Holocene. The difference between MIS 1 and MIS 11 is further reflected in the quantitative climatic characteristics: annual precipitation consistently higher than the Holocene maximum throughout the MIS 11, mean temperature of the warmest month consistently higher and continentality index consistently lower than during the Holocene (Fig. 7, bottom panels).

Because lake productivity proxies (BioSi, TOC, TN, $\delta^{13} \mathrm{C}_{\text {org }}$; Fig. 7) are from different sites, we compare the patterns rather than the amplitudes of the proxy signals. Unlike in the Holocene, which shows a distinct trend towards midlate Holocene productivity maximum, the MIS 11 records show the sustained stable high level of primary productivity throughout MIS 11. Diatom abundance is at least twice as high during MIS 11 in part because of less dilution with clastic material at the BDP-96 site but mostly because the composition of diatom assemblage is very different and nonanalogous to that of the Holocene (Khursevich et al., 2001).

The abundance of illite and the smectite layer index during MIS 11 at the BDP-96 site are lower than those during the Holocene at the BDP-93 site (Fig. 7). Given the distance between sites (Fig. 2), we do not overemphasize the significance of this observation. We note, however, that from the standpoint of mineralogy proxies only the late MIS 11 interglacial (ca. 404-400 ka) appears analogous to midlate Holocene. For the most part, MIS 11 interval in the Lake Baikal mineralogical record appears more like the early part of the Holocene. In terms of climatic interpretation of clay mineralogy this implies higher effective moisture and less pronounced seasonality (decreased continentality) of regional climate as compared with the regional climate of the past 6 kyr. These conclusions are in fair agreement with the implications from the BDP-99 palynological record.

The characteristic succession in the dominant regional vegetation during early-mid-Holocene (Picea obovata $\rightarrow$ Abies sibirica $\rightarrow$ Pinus sylvestris; highlighted by arrows in Fig. 7) reflects warming and the decline in regional moisture availability (Prokopenko et al., 2007) with transition to more continental mid-late Holocene climate (Tarasov et al., 2007, 2009). A somewhat similar succession is observed toward the end of the Lake Baikal MIS 11 interglacial, between ca. 405 and $400 \mathrm{ka}$, also associated with a gradual shift towards somewhat drier and more continental climate (Fig. 7). This comparison suggests that the closest climate analog to the elapsed portion of the Holocene is the very latest part of the MIS 11 interglacial. During MIS 11, this characteristic succession in arboreal vegetation around Lake Baikal appears to be tied into an orbital configuration similar to that during the Holocene: during both interglacials it occurred as the perihelion was changing from summer to autumn timing (Fig. 7, top). Even though monthly insolation values have been quite similar, there is, however, a significant difference in phasing of the precession index maximum and obliquity maximum between MIS 11 and the Holocene. The differences in the alignment of obliquity and precession index are potentially problematic for direct comparisons of the Holocene and MIS 11 climate, even for the reasonably analogous portions of these interglacials.

In marine oxygen isotope records, the gradual $\delta^{18} \mathrm{O}$ change during the early MIS 11 above Termination $\mathrm{V}$ may be viewed as evidence for a longer-than-usual global deglaciation at a time of subdued amplitudes of orbital forcing (e.g. Figs. 2, 3). In this view, the extended deglaciation contributes to the total estimated duration of the MIS 11 interglacial making this estimate excessive. The new climate record from Lake Baikal provides an important constraint on this line of argument by indicating that above $50^{\circ} \mathrm{N}$ in continental Eurasia the forest vegetation typical of a full-scale interglacial was established no later than $424 \mathrm{ka}$.

\section{Conclusions}

Understanding past climate of the MIS 11 is important given that the Earth's orbital configuration during this interglacial is the most recent analog to the orbital configuration of the current interglacial. Finding well-resolved paleoclimate records of the MIS 11 on land is difficult because of the discontinuous nature of most continental sedimentary archives. Lake Baikal, the deepest in the world, is one of the few basins in upper mid-latitude Eurasia which preserved continuous sequences of several Pleistocene climatic cycles. The MIS 11 interglacial interval in Lake Baikal is well constrained and recovered at several sites. 
The Baikal record has a robust orbital time scale constructed based on lacustrine productivity records. This age model is independent, i.e. it is not a correlation-based derivative of some other regional age model. Among multiple paleoclimate proxies preserved in Baikal sediments, pollen is very important as it makes possible to establish correlations with other regional records from Eurasia, in which palynological records are used for identifying past interglacials. In the best-resolved Baikal records including those reported here, the estimates of the duration of past interglacials derived from lacustrine productivity records (biogenic silica, diatom abundance, organic matter content) closely agree with those derived from palynological records.

As shown by the records from two contrasting depositional settings in the lake, MIS 11 interval in the Baikal record is the thickest among the last four interglacial intervals. Because this interval was not associated with anomalies in lithologic composition, sediment mineralogy and/or sedimentation rates, the thickness of the MIS 11 interglacial interval in Lake Baikal is an adequate representation of the extended duration of this interglacial, which corresponds to two precession peaks in the orbital age model.

The Lake Baikal MIS 11 interglacial interval in two drill cores $245 \mathrm{~km}$ apart was characterized by nearly the same composition of planktonic diatom assemblage. The same pattern of changes in the relative abundance and the same succession of co-dominant planktonic species confirmed the basin-wide nature of the interglacial planktonic diatom assemblage in Lake Baikal and allowed identifying biostratigraphic boundaries to correlate the records and establish the common age control points in two distant drill core records.

Productivity proxy signals in bulk sedimentary organic matter at both BDP-99 and BDP-96 drill sites indicated sustained high accumulation rates of organic matter indicative of prolonged stable interglacial conditions. The relative lead of OM-based proxy signals relative to biogenic silica at the onset of the Lake Baikal MIS 11 interglacial and the trend of increasing $\mathrm{C} / \mathrm{N}$ ratio during the interglacial appear somewhat similar to those in the Holocene records. The BDP-99 proxy records in the vicinity of the delta of the largest Baikal tributary were least variable suggesting high sustained level of primary productivity. Terrestrial organic matter does not appear to be a dominant source of bulk OM in the MIS 11 sediments at either of the drill sites.

Palynological record from the BDP-99 drill core indicates that coniferous forests continuously dominated in the region during the Lake Baikal MIS 11 interglacial. The current age model constrains the duration of this forest phase at ca. 424$396 \mathrm{ka}$ (the lowermost portion of the MIS 11 interval ca. 429$424 \mathrm{ka}$ is believed to not have been recovered in the BDP-99 drill core). The distinct feature of the regional MIS 11 terrestrial vegetation record is a prolonged (ca. 420-405 ka) interval of "dark conifer optimum" with substantial abundance of fir (Abies sibirica). During the Holocene, forests of a somewhat similar composition (yet, with lower Abies abundance) existed around Lake Baikal at ca. 9-7 ka (Tarasov et al., 2007; Bezrukova et al., 2008). A shift to a more modern-type vegetation with a more substantial participation of pine and larch has occurred only towards the end of the Lake Baikal MIS 11 interglacial, ca. $402 \mathrm{ka}$ in our age model.

The warmest, most humid and least continental climate in the Baikal region during MIS 11 is recorded between 421 and $400 \mathrm{ka}$; the climate most similar to that of the elapsed portion of the Holocene (yet still warmer and less continental) is recorded in the latest portion of "MIS 11c" between 406 and $396 \mathrm{ka}$. Two intervals of the MIS 11 record at ca. 411410 and $405-404 \mathrm{ka}$ are characterized by pollen composition indicative of regional millennial-scale cooling episodes.

The sediment mineralogy record of the MIS 11 interglacial studied in the BDP-96-2 drill core indicates a rather stable depositional setting with no apparent dramatic variations in sources of the mineral component of Baikal sediments. Two key climate-sensitive indices of weathering in the Baikal watershed, the smectite layer index and the abundance of illite, exhibit general trends consistent with the changes in the composition of secondary clay minerals during the Holocene. Similar to the Holocene, illitization was apparently an important process in the Baikal watershed during MIS 11. The current understanding of the nature of weathering indices in the Baikal record suggests that the first half of the Lake Baikal MIS 11 interglacial could have been characterized by more humid climate with subdued seasonality as compared with climate of the late Holocene. This inference is consistent with the changes observed in the BDP-99 palynological record and quantitative climate parameters reconstructed from pollen record using best modern analog approach.

Historically, linking marine and terrestrial records has been difficult, particularly in the time range beyond the last interglacial, where age model uncertainties in discontinuous records become difficult to resolve. Lake Baikal drill cores provide a new type of a continental record. On one hand, the complete "continental" set of Lake Baikal paleoclimate proxies (from sediment mineralogy and lake productivity to diatom stratigraphy and terrestrial pollen) make it possible to establish correlations with stratigraphic blocks of the existing discontinuous continental archives; on the other hand, robust orbitally-tuned time scale allows reliable correlation with individual stages and substages in marine oxygen isotope records. The current Lake Baikal MIS 11 contribution may be viewed as an important case study underscoring the potential and the significance of marine-terrestrial correlations as a tool for reconstructing climates of the past interglacials.

Acknowledgements. The international effort of the Lake Baikal Drilling Project was has been supported by the Siberian Branch of Russian Academy of Sciences, the US National Science Foundation grant EAR-9614770, Science and Technology Agency of Japan. This study was supported by grant EAR-0602309 from the US National Science Foundation to A. Prokopenko, by the Department of Geological Sciences, University of South Carolina and by 
Russian Foundation for Basic Research grants 08-05-00680 and 09-05-00123. Quantitative climate reconstruction is a contribution of P. Tarasov and E. Bezrukova to the German Research Foundation (DFG) project "Comparison of climate and carbon cycle dynamics during late Quaternary interglacials using a spectrum of climate system models, ice-core and terrestrial archives". We thank O. Karabanova for sediment processing and microslide preparation, S. Fedenya for help with diatom analysis and N. V. Kulagina, P. P. Letunova, A. A. Abzaeva for help with palynological analysis. The research on the Baikal MIS 11 interval was conducted as a part of the effort by the Inter-Congress INQUA MIS 11 Working Group (2000-2007) to better constrain climatic characteristics of this important interval. We thank E. Wolff for patience and encouragement of this contribution, S. Desprat, A. Mackay and C. Tzedakis for helpful reviews and suggestions. The publication costs are covered via the DGF grant TA 540/1 to P. Tarasov.

Edited by: P. Tzedakis

\section{References}

BDP Members: Continuous paleoclimate record of last 5 MA from Lake Baikal, Siberia, EOS American Geophysical Union, Transactions, 78, 597-604, 1997.

BDP Members: The new BDP-98 600-m drill core from Lake Baikal: a key late Cenozoic sedimentary section in continental Asia, Quat. Intl., 80-81, 19-36, 2001.

BDP Members: A new Quaternary record of regional tectonic, sedimentation and paleoclimate changes from drill core BDP-99 at Posolskaya Bank, Lake Baikal, Quat. Intl., 136, 105-121, 2005.

Berger, A., Loutre, M. F., and Tricot, C.: Insolation and Earth's orbital periods, J. Geophys. Res., 98, 10341-10362, 1993.

Berglund, B. E. and Ralska-Jasiewiczowa, M.: Pollen analysis and pollen diagrams, in: Handbook of Holocene Palaeoecology and Palaeohydrology, edited by: Berglund, B. E., Interscience, New York, 455-484, 1986.

Bethke, C. M. and Altaner, S. P.: Layer-by-layer mechanism of smectite illitisation and application to a new rate law, Clay. Clay Miner., 34, 136-145, 1986.

Bezrukova, E. V.: Peculiarities of the sub-recent spore-pollen spectra of Pribaikalie, Geografiya i Prirodnye Resursy (Geography and Natural Resources), 1, 142-147, 1998 (in Russian).

Bezrukova, E. V., Krivonogov, S. K., Abzaeva, A. A., Vershinin, K. E., Letunova, P. P., Orlova, L. A., Mioshi, N., Krapivina, S. M., and Kawamuro, K.: Landscapes and climate of the Baikal Region in the Late Glacial and Holocene, Russ. Geol. Geophys.+, 46, 21-33, 2005.

Bezrukova, E. V., Belov, A. V., Letunova, P. P., Abzaeva, A. A., Kulagina, N. V., Fisher, E. E., Orlova, L. A., Sheifer, E. V., and Voronin, V. I.: Peat biostratigraphy and Holocene climate in the northwestern mountain periphery of Lake Baikal, Russ. Geol. Geophys.+, 49, 413-421, 2008.

Colman, S. M., Jones, G. A., Rubin, M., King, J. W., Peck, J. A., and Orem, W. H.: AMS radiocarbon analyses from Lake Baikal, Siberia: Challenges of dating sediments from a large, oligotrophic lake., Quaterny Sci. Rev., 15, 669-684, 1996.
Demory, F., Nowaczyk, N. R., Witt, A., and Oberhänsli, H.: High-resolution magnetostratigraphy of late quaternary sediments from Lake Baikal, Siberia: timing of intracontinental paleoclimatic responses, Global Planet. Change, 46, 167-186, 2005.

Eberl, D.,Środoñ, J., and Northrop, H. R.: Potassium fixation in smectite by wetting and drying, in: Geochemical processes at mineral surfaces, edited by: Davis, J. A., Symposium Series vol. 323, American Chemical Society, 296-326, 1986.

EPICA Community Members: Eight glacial cycles from an Antarctic ice core, Nature, 429, 623-628, 2004.

Goldberg, E. L., Grachev, M. A., Chebykin, E. P., Phedorin, M. A., Kalugin, I. A., Khlystov, O. M., and Zolotarev, K. V.: Scanning SRXF analysis and isotopes of uranium seires from bottom sediments of Siberian lakes for high-resolution climate reconstructions, Nucl. Instrum. Meth. A, 543, 250-254, 2005.

Granoszewski, W., Demske, D., Nita, M., Heumann, G., and Andreev, A. A.: Vegetation and climate variability during the Last Interglacial evidenced in the pollen record from Lake Baikal, Global Planet. Change, 46, 187-198, 2005.

Howard, W. R.: A warm future in the past, Nature, 388, 418-419, 1997.

Karabanov, E. B.: Pleistocene-Holocene paleoclimate record of Lake Baikal, upubl. Ph.D Thesis, Geological Sciences, University of South Carolina, Columbia, 184 pp., 1997.

Karabanov, E. B., Prokopenko, A. A., Williams, D. F., Khursevich, G. K., Kuzmin, M. I., Bezrukova, E. V., and Gvozdkov, A. N.: High-resolution MIS 11 record from the continental sedimentary archive of Lake Baikal, Siberia, in: Earth's Climate and Orbital Eccentricity: The Marine Isotope Stage 11., edited by: Droxler, A., Poore, R., and Burckle, L., American Geophysical Union, Washington, 223-230, 2003.

Kukla, G.: Continental Records of MIS 11, in: Earth's Climate and Orbital Eccentricity: The Marine Isotope Stage 11., edited by: Droxler, A., Poore, R., and Burckle, L., American Geophysical Union, Washington, 207-211, 2003.

Khursevich, G. K., Karabanov, E. B., Prokopenko, A. A., Williams, D. F., Kuzmin, M. I., Fedenya, S. A., and Gvozdkov, A. A.: Insolation regime in Siberia as a major factor controlling diatom production in Lake Baikal during the past 800,000 years, Quatern. Int., 80-81, 47-58, 2001.

Laskar, J., Robutel, P., Joutel, F., Gastineau, M., Correia, A. C. M., and Levrard, B.: A long-term numerical solution for the insolation quantities of the Earth, Astron. Astrophys., 428, 261285, 2004.

Lisiecki, L. E. and Raymo, M. E.: A Pliocene-Pleistocene stack of 57 globally distributed benthic $\delta^{18} \mathrm{O}$ records, Paleoceanography, 20, PA1003, doi:10.1029/2004PA001071, 2005.

Loutre, M. F. and Berger, A.: Marine Isotope Stage 11 as an analogue for the present interglacial, Global Planet. Change, 36, 209-217, 2003.

Mackay, A. W.: The paleoclimatology of Lake Baikal: A diatom synthesis and prospectus, Earth-Sci. Rev., 82, 181-215, 2007.

Mackay, A. W., Karabanov, E. B., Leng, M. J., Sloane, H. J., Morley, D. W., Panizza, V. N., Khursevich, G. K., and Williams, D. F.: Reconstructing hydrological variability in Lake Baikal during MIS 11: an application of oxygen isotope analysis of diatom silica, J. Quaternary Sci., 23, 365-374, 2008. 
McManus, J. F., Oppo, D. W., Cullen, J. L., and Healey, S. L.: Marine Isotope Stage 11 (MIS 11): Analog for Holocene and future climate? , in: Earth's Climate and Orbital Eccentricity: The Marine Isotope Stage 11, edited by: Droxler, A., Poore, R., and Burckle, L., American Geophysical Union, Washington, 69-85, 2003.

Nakamura, T., Oda, T., Tanaka, A., Horiuchi, K.: High precision ${ }^{14} \mathrm{C}$ age estimation of bottom sediments of Lake Baikal and Lake Hovsgol by AMS. Gekkan Chikyu, Special No.42, Kaiyoshuppansha, Tokyo, 20-31, 2003 (in Japanese).

Nitychoruk, J., Binka, K., Ruppert, H., and Schneider, J.: Holsteinian Interglacial = Marine Isotope Stage 11?, Quaternary Sci. Rev., 25, 3-23, 2006.

Peck, J., King, J., Colman, S. M., and Kravchinsky, V.: An 84kyr paleomagnetic record from the sediments of Lake Baikal, Siberia, Geophys. Res. Lett., 101, 11365-11386, 1996.

Prell, W. L., Imbrie, J., Martinson, D. G., Morley, J. J., Pisias, N. G., Shackleton, N. J., and Streeter, H. F.: Graphic correlation of oxygen isotope stratigraphy application to the Late Quaternary, Paleoceanography, 1, 137-162, 1986.

Prentice, C. I., Guiot, J., Huntley, B., Jolly, D., and Cheddadi, R.: Reconstructing biomes from palaeoecological data: a general method and its application to European pollen data at 0 and $6 \mathrm{ka}$, Clim. Dynam., 12, 185-194, 1996.

Prokopenko, A. A., Karabanov, E. B., Williams, D. F., Kuzmin, M. I., Shackleton, N. J., Crowhurst, S. J., Peck, J. A., Gvozdkov, A. N., and King, J. W.: Biogenic silica record of the Lake Baikal response to climatic forcing during the Brunhes chron, Quaternary Res., 55, 123-132, 2001a.

Prokopenko, A. A., Karabanov, E. B., Williams, D. F., Kuzmin, M. I., Khursevich, G. K., and Gvozdkov, A. A.: The detailed record of climatic events during the past 75,000 yrs BP from the Lake Baikal drill core BDP-93-2, Quatern. Int., 80-81, 59-68, 2001 b.

Prokopenko, A. A. and Williams, D. F.: Glacial/Interglacial changes in the carbon cycle of Lake Baikal, in: Long Continental Records from Lake Baikal, edited by: Kashiwaya, K., Springer, Tokyo, 163-185, 2003

Prokopenko, A. A., Hinnov, L. A., Williams, D. F., and Kuzmin, M. I.: Orbital forcing of continental climate during the Pleistocene: a complete astronomically tuned climatic record from Lake Baikal, SE Siberia, Quaternary Sci. Rev., 25, 3431-3457, 2006.

Prokopenko, A. A., Khursevich, G. K., Bezrukova, E. V., Kuzmin, M. I., Boes, X., Williams, D. F., Fedenya, S. A., Kulagina, N. V., Letunova, P. P., and Abzaeva, A. A.: Paleoenvironmental proxy records from Lake Hovsgol, Mongolia, and a synthesis of Holocene climate change in the Lake Baikal watershed, Quaternary Res., 68, 2-17, 2007.

Prokopenko, A. A., Khursevich, G. K., Kuzmin, M. I., and Kawai, T.: Productivity cycles in Lake Hovsgol, NW Mongolia, during the last $1 \mathrm{Ma}$ and the age model of the HDP-04 drill core, Quatern. Int., 205, 111-125, 2009.

Raynaud, D., Barnola, J.-M., Souchez, R., Reginald, L., Petit, J.-R., Duval, P., and Lipenkov, V. Y.: Paleoclimatology: The record for marine isotopic stage 11, Nature, 436, 39-40, 2005.

Reille, M., Beaulieu, J.-L., Svobodova, H., Andrieu-Ponel, V., and Goeury, C.: Pollen analytical biostratigraphy of the last five climatic cycles from a long continental sequence from the Velay region (Massif Central, France), J. Quaternary Sci., 15, 665685,2000
Rioual, P. and Mackay, A. W.: A diatom record of centennial resolution for the Kazantsevo Interglacial stage in Lake Baikal (Siberia), Global Planet. Change, 46, 199-219, 2005.

Ruddiman, W. F.: The early anthropogenic hypothesis a year later, Climatic Change, 69, 427-434, 2005.

Shichi, K., Kawamuro, K., Takahara, H., Hase, Y., Maki, T., and Miyoshi, N.: Climate and vegetation changes around Lake Baikal during the last 350,000 years, Palaeogeogr. Palaeocl., 248, 357-375, 2007.

Solotchina, E. P., Prokopenko, A. A., Vasilevsky, A. N., Gavshin, V. M., Williams, D. F., and Kuzmin, M. I.: Simulation of XRD patterns as an optimal technique for studying glacial and interglacial clay mineral associations in bottom sediments of Lake Baikal, Clay Miner., 37, 105-119, 2002.

Solotchina, E. P.: Structural typomorphism of clay minerals in sedimentary sections and weathering profiles, GEO Academic Publishing House, Novosibirsk, 2009 (in Russian).

Solotchina, E. P., Prokopenko, A. A., Kuzmin, M. I., Solotchin, P. A., and Zhdanova A. N.: Climate signals in sediment mineralogy of Lake Baikal and Lake Hovsgol during the LGM-Holocene transition and the 1-Ma carbonate record from the HDP-04 drill core, Quatern. Int., 205, 38-52, 2009.

Środoñ, J., Morgan, D. J., Eslinger, E. V., Eberl, D., and Karlinger, M. R.: Chemistry of illite-smectite and end-member illite, Clay. Clay Miner., 34, 368-378, 1986.

Tani, Y., Kurihara, K., Nara, F., Itoh, N., Soma, M., Soma, Y., Tanaka, A., Yoneda, M., Hirota, M., and Shibata, Y.: Temporal changes in phytoplankton community of southern basin of Lake Baikal over the last 24,000 years recorded by photosynthetic pigments in a sediment core., Org. Geochem., 33, 1621-1634, 2002.

Tarasov, P., Bezrukova, E., Karabanov, E., Nakagawa, T., Wagner, M., Kulagina, N., Letunova, P., Abzaeva, A., Granoszewski, W., and Riedel, F.: Vegetation and climate dynamics during the Holocene and Eemian interglacials derived from Lake Baikal pollen records, Palaeogeogr. Palaeocl., 252, 440-457, 2007.

Tarasov, P. E., Bezrukova, E. V., and Krivonogov, S. K.: Late Glacial and Holocene changes in vegetation cover and climate in southern Siberia derived from a $15 \mathrm{kyr}$ long pollen record from Lake Kotokel, Clim. Past, 5, 285-295, 2009, http://www.clim-past.net/5/285/2009/.

Tarasov, P. E., Granoszewski, W., Bezrukova, E. V., Brewer, S., Nita, M., Abzaeva, A., and Oberhansli, H.: Quantitative reconstruction of the last interglacial vegetation and climate based on the pollen record from Lake Baikal, Russia, Clim. Dynam., 25, 625-637, 2005.

Traverse, A.: Paleopalynology, Allen and Unwin, Boston, 600 pp., 1988

Tzedakis, P. C., Andrieu, V., de Beaulieu, J. L., Crowhurst, S., Follieri, M., Hooghiemstra, H., Magri, D., Reille, M., Sadori, L., Shackleton, N. J., and Wijmstra, T. A.: Comparison of terrestrial and marine records of changing climate of the last 500,000, Earth Planet. Sc. Lett., 150, 171-176, 1997.

Votintzev, K. K.: Hydrochemistry of Lake Baikal, Nauka, Moscow, 311 pp., 1961 (in Russian).

Williams, D. F., Peck, J., Karabanov, E. B., Prokopenko, A. A., Kravchinsky, V., King, J., and Kuzmin, M. I.: Lake Baikal record of continental climate response to orbital insolation during the past 5 million years, Science, 278, 1114-1117, 1997. 